\title{
Dual Enzyme-like Performances of PLGA Grafted Maghemite Nanocrystals and Their Synergistic Chemo/Chemodynamic Therapy for Human Lung Adenocarcinoma A549 Cells
}

\section{Xueqin Wang ( $\nabla$ wangxq0708@163.com )}

Henan University of Technology https://orcid.org/0000-0001-8744-850X

Miao Cui

Henan University of Technology

Fan Ouyang

Henan University of Technology

Yuqi Guo

Henan Provincial People's Hospital

Ruifang Li

Henan University of Technology

Shaofeng Duan

Henan university

Tiandi Xiong

Henan University of Technology

Huiru Zhang

Henan University of Technology

Yunlong Wang

Henan Bioengineering Research Center

\section{Research}

Keywords: Maghemite nanoparticles, POD- and CAT-like activity, Reactive oxygen species, Lung adenocarcinoma A549 cells

Posted Date: November 19th, 2020

DOl: https://doi.org/10.21203/rs.3.rs-108083/v1

License: (9) This work is licensed under a Creative Commons Attribution 4.0 International License.

Read Full License 



\title{
Dual enzyme-like performances of PLGA grafted maghemite nanocrystals and their synergistic chemo/chemodynamic therapy for human lung adenocarcinoma A549 cells
}

\author{
Xueqin Wang ${ }^{1}$, Miao Cui ${ }^{1}$, Fan Ouyang ${ }^{1}$, Yuqi Guo ${ }^{3}$, Ruifang $\mathrm{Li}^{1}$, Shaofeng Duan ${ }^{4 *}$, \\ Tiandi Xiong ${ }^{1}$, Huiru, Zhang ${ }^{1 *}$, Yunlong Wang ${ }^{2 *}$ \\ ${ }^{1}$ College of Bioengineering, Henan University of Technology, Zhengzhou, Henan 450001, P.R. China ; \\ ${ }^{2}$ Henan Bioengineering Research Center, Zhengzhou, 450046, P.R.China; ${ }^{3}$ Henan Provincial People's \\ Hospital, Zhengzhou 450003, P.R. China: ${ }^{4}$ School of Pharmacy, Henan University, Kaifeng, Henan 475004, \\ P.R. China. \\ * Corresponding authors: Shaofeng Duan, Tel: + 86371 22822134, E-mail address: sduan@henu.edu.cn, \\ School of Pharmacy, Henan University, Kaifeng, Henan 475004, P.R. China; Huiru, Zhang, Tel: + 86371 \\ 67756317, E-mail address: zhr67@163.com, College of Bioengineering, Henan University of Technology, \\ Zhengzhou, Henan 450001, P.R. China; Yunlong Wang, Tel: + 86371 67999699, E-mail address: \\ biowyl@126.com, Henan Bioengineering Research Center, Zhengzhou, 450018, P.R.China.
}

\begin{abstract}
Advancing nanocatalytic therapies of tumors formed on non-toxic but catalytically active inorganic nanoparticles (NPs) have aroused great interest in tumor therapy recently, but the limited reactive oxygen species within tumors may limit treatment efficiency. Therefore, the combination of chemotherapy and chemodynamic therapy is a promising treatment strategy. Herein, poly(lactic
\end{abstract}


acid-co-glycolic acid) (PLGA) grafted- $\gamma-\mathrm{Fe}_{2} \mathrm{O}_{3}$ nanoparticles ( $N P$ PLGA) with dual response of endogenous peroxidase (POD)- and catalase (CAT)-like activities has been reported. On the one hand, the $N P_{\text {PLGA }}$ could serve as a drug delivery system for doxorubicin (DOX), an anti-tumor drug used to treat lung adenocarcinoma A549 cells. On the other hand, based on the mimetic enzyme

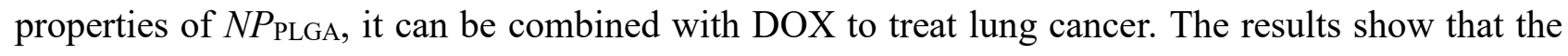
$N P_{P L G A}$ could be simulated the CAT-like activity to decompose hydrogen peroxide $\left(\mathrm{H}_{2} \mathrm{O}_{2}\right)$ into $\mathrm{H}_{2} \mathrm{O}$ and $\mathrm{O}_{2}$ under neutral tumor microenvironment, so as to reduce the oxidative damage caused by $\mathrm{H}_{2} \mathrm{O}_{2}$ to lung adenocarcinoma A549 cells. Under acidic microenvironment, $N P_{\text {PLGA }}$ could simulate POD-like activity to effectively catalyze the decomposition of $\mathrm{H}_{2} \mathrm{O}_{2}$ to produce highly toxic hydroxyl radicals $(\bullet \mathrm{OH})$ to induce the death of tumor-cell through regular catalytic reaction of Fenton. Furthermore, the POD-like activity of $N P_{\text {PLGA }}$ synergistic with DOX can promote the apoptosis and destruction of A549 cells and enhance the antitumor impact of DOX-NP PLGA. Therefore, this study provides an efficacious dual inorganic biomimetic nanozyme-based nanoplatform for lung tumor treatment.

Keywords: Maghemite nanoparticles, POD- and CAT-like activity, Reactive oxygen species, Lung adenocarcinoma A549 cells

\section{Introduction}

Recently, chemodynamic therapy (CDT) formed on nontoxic but catalytically active inorganic nanozymes for intratumoral generation of high-toxic reactive oxygen species (ROS) has been 
widely studied in tumor therapy due to its high specificity and diminished invasiveness [1]. Within the period of the CDT procedure, endogenous hydrogen peroxide $\left(\mathrm{H}_{2} \mathrm{O}_{2}\right)$ is decomposed into ROS and hydroxyl radicals $(\cdot \mathrm{OH})$ through the medium acidic tumor microenvironment $(\mathrm{TME})$ by an intratumoral Fenton or Fenton-like reaction by metal catalysts (e.g., Fe, Mn, Cu, etc.). Nanozyme is a kind of nanomaterial with natural mimic enzyme catalytic activity [2,3]. As a new generation of artificial enzyme, nanoenzyme has the advantages of simple synthesis [4], adjustable catalytic activity [5,6], high stability, low cost and easy operation $[7,8]$. They have become a promising alternative to natural enzymes and have attracted extensive exploration by biomedical researchers [9-11].

Maghemite $\left(\gamma-\mathrm{Fe}_{2} \mathrm{O}_{3}\right)$ and magnetite $\left(\mathrm{Fe}_{3} \mathrm{O}_{4}\right)$ nanoparticles (NPs) are two main iron oxide nanoparticles (IONPs) that are often utilized in a diversity of biomedical functionalities, including magnetic targeting and drug/gene delivery [12-14], tumor therapy [15, 16], magnetic resonance imaging [17, 18], cell labeling and isolation [19-21], magnetic biosensors [22, 23], and magnetic hyperthermia $[24,25]$. However, ferrous $\mathrm{Fe}_{3} \mathrm{O}_{4}$ may increase the risk of toxicity and chemical instability $[26,27]$. Therefore, $\gamma-\mathrm{Fe}_{2} \mathrm{O}_{3}$ can be used as a good candidate for long-term biomedical and clinical applications. Recently, it has been reported that $\mathrm{Fe}_{3} \mathrm{O}_{4}$ and $\gamma-\mathrm{Fe}_{2} \mathrm{O}_{3} \mathrm{NPs}$ have intrinsic enzyme simulation activity and have been developed as catalysts for Fenton reaction, which can catalyze the formation of $\bullet \mathrm{OH}$ in situ $\mathrm{H}_{2} \mathrm{O}_{2}$ in solid tumors, thus leading to the death of cancer cells [28-30]. Moreover, $\mathrm{Fe}_{3} \mathrm{O}_{4}$ and $\gamma-\mathrm{Fe}_{2} \mathrm{O}_{3}$ NPs showed $\mathrm{pH}$-dependent peroxidase (POD)-like as well as catalase (CAT)-like performances [31,32]. A typical example of its inherent POD-like activity is that IONPs is able to catalyze the POD oxidation substrates when $\mathrm{H}_{2} \mathrm{O}_{2}$ is available in acidic solutions to generate blue products [28]. Mechanism studies have shown that IONPs initially reduce 
$\mathrm{H}_{2} \mathrm{O}_{2}$ to create $\cdot \mathrm{OH}$, which then organizes the oxidation of the studied substrate [33-35]. Dissimilar with the natural POD, IONPs mostly lost POD-like performance at neutral $\mathrm{pH}$. However, we found that $\gamma-\mathrm{Fe}_{2} \mathrm{O}_{3} \mathrm{NPs}$ directly catalyzed $\mathrm{H}_{2} \mathrm{O}_{2}$ to generate $\mathrm{H}_{2} \mathrm{O}$ and oxygen $\left(\mathrm{O}_{2}\right)$ under such a condition, which is called CAT-like activity, and can protect cells from the stress of oxidative damage in this study [36].

In the process of cell metabolism, $\mathrm{O}_{2}$ undergoes a series of single-electron reduction to form ROS, including $\mathrm{O}_{2}{ }^{-}, \mathrm{O}_{2}{ }^{2-}, \cdot \mathrm{OH}, \cdot \mathrm{OOH}$ radicals, $\mathrm{H}_{2} \mathrm{O}_{2}$, etc [37]. Low-dose ROS play an important role in cell proliferation, signal transduction, differentiation, migration, and body's resistance to the invasion of pathogen [37]. Although, unusually increased ROS levels will devastate the redox homeostasis, result in oxidative stress, and seriously harm the function and infrastructure of cellular macromolecules. The systems of enzyme including glutathione peroxidase (GPx), superoxide dismutase (SOD), and CAT protect cells from ROS damage by regulating intracellular ROS levels. Nanozyme can also regulate intracellular ROS levels [38,39]. The ROS scavenging ability of nanozyme mainly comes from the simulation activity of SOD, which converts superoxide into $\mathrm{H}_{2} \mathrm{O}_{2}$ and then into $\mathrm{O}_{2}$ and $\mathrm{H}_{2} \mathrm{O}$, thus reducing intracellular ROS level and enhancing cell activity. ROS is produced by converting $\mathrm{H}_{2} \mathrm{O}_{2}$ into $\bullet \mathrm{OH}$ free radicals through its POD-like activity. The reaction of iron-mediated Fenton turns endogenous $\mathrm{H}_{2} \mathrm{O}_{2}$ into highly toxic $\cdot \mathrm{OH}$, leading to irreversible oxidative damage against tumor cells.

CDT-based Fenton reaction has been proposed as an efficacious strategy for treatment of cancers. However, the limited $\mathrm{H}_{2} \mathrm{O}_{2}$ concentration in tumor cells severely limits the efficacy of CDT [40]. Thus, combining with CDT with other therapeutic methods, including chemotherapy [40], and photothermal treatment [41], is a marvelous way to improve the anticancer impact. Here, we 
combined CDT with chemotherapy drug DOX to effectively treat lung adenocarcinoma A549 cells. As shown in Scheme 1, NPPLGA was first prepared with superparamagnetic $\gamma-\mathrm{Fe}_{2} \mathrm{O}_{3} \mathrm{NPs}$ as the core, followed by the surface modification with poly (lactic-co-glycolic acid) (PLGA) and the loading of the chemotherapy drug DOX. This formed nanocatalyst drug DOX-NPPLGA, through a reaction similar to Fenton under acidic TME, will show POD-like activity, produce highly toxic $\cdot \mathrm{OH}$, induce the death of cancer A549 cells, augment the sensibility of A549 cells to DOX, and enhance the therapeutic effect of CDT. In the neutral TME, the nanocatalyst exhibited CAT-like activity and could decompose $\mathrm{H}_{2} \mathrm{O}_{2}$ into $\mathrm{H}_{2} \mathrm{O}$ and $\mathrm{O}_{2}$, thus reducing the oxidative damage of $\mathrm{H}_{2} \mathrm{O}_{2}$ to A549 cells. Furthermore, the synergistic anti-tumor effect and related mechanism of $N P_{P L G A}$ and DOX-NP ${ }_{P L G A}$ on A549 cells were further studied in detail.

(A)

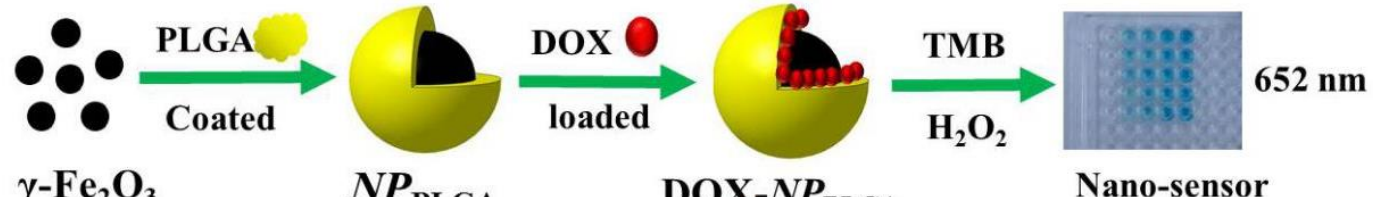

(B)

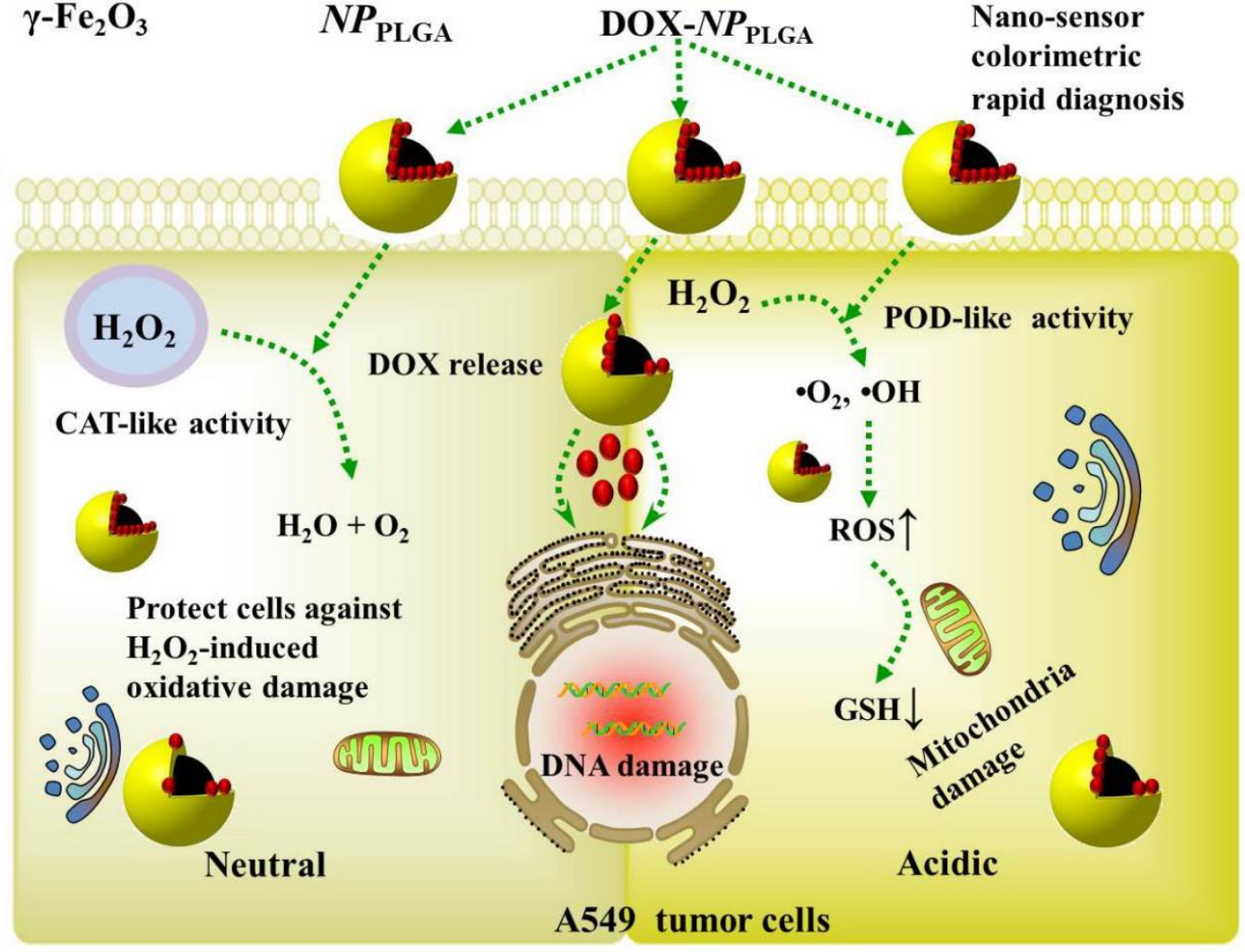


Scheme. 1 Schematic diagram of the functional pattern of DOX-NPPLGA and its enhanced anti-tumor effect. A Preparation of DOX-loaded $N P_{P L G A}$ and colorimetric determination in lung adenocarcinoma A549 cells. B In a neutral TME, DOX-NPPLGA displayed CAT-like activity by decomposing $\mathrm{H}_{2} \mathrm{O}_{2}$ into $\mathrm{H}_{2} \mathrm{O}$ and $\mathrm{O}_{2}$. In an acidic TME, DOX-NPPLGA released DOX and exhibited POD-like activity to produce highly toxic $\cdot \mathrm{OH}$, which caused the growth of ROS accumulation as well as the decrease of GSH in tumor A549 cells, and the further synergistic effect with DOX, causing efficient cell death.

\section{Experimental}

\section{Materials}

Human lung adenocarcinoma A549 cells was from the Shanghai Cell Bank of the Chinese Academy of Sciences (Shanghai, China). CAT from the liver of bovine (2000-5000 $\mathrm{U} \mathrm{mg}^{-1}$ ), POD from horseradish VI (250-330 $\left.\mathrm{U} \mathrm{mg}^{-1}\right)$. The RPMI-1640 cell culture medium and fetal bovine serum (FBS) were from Gibco Invitrogen Corporation (CA, USA). PLGA (lactide/glycolide molar ratio of 50: 50, MW=7000-17,000), 3-(4,5-dimethylthiazol-2-diphenyl-tetrazolium) bromide (MTT), 3,3',5,5'-tetramethylbenzidine (TMB), $\mathrm{H}_{2} \mathrm{O}_{2}$, potassium ferrocyanide (Perls reagent), dimethyl sulfoxide (DMSO), Hoechst 33258, Triton X-100 solution, and paraformaldehyde were obtained from Sigma-Aldrich (St. Louis, MO,USA). DOX was purchased from Aladdin Bio-Chem Technology Co., Ltd (Shanghai, China). Fluorescent dye FITC and 4, 6 diamidino-2-phenylindole (DAPI) were obtained from Molecular Probes, Inc. (Eugene, OR, USA). ROS assay and Annexin V-FITC apoptosis assay kits were obtained from Keygen Biotech Co., Ltd. (Nanjing, China). CAT assay and reduced glutathione (GSH) assessment kits were obtained from solarbio science and 
technology Co., Ltd (Beijing, China). Other chemicals and specimens were from local commercial providers and the grade of the analytical reagents, unless otherwise mentioned.

\section{Synthesis and characterization of NPPLGA}

The magnetic $\gamma-\mathrm{Fe}_{2} \mathrm{O}_{3}$ NPs were synthesized by chemical coprecipitation method $[42,43]$, then PLGA was grafted to prepare $N P_{P L G A}$. The morphology, size, crystal structure and stability of $\gamma-\mathrm{Fe}_{2} \mathrm{O}_{3} \mathrm{NPs}$ and $N P_{P L G A}$ were characterized in our previous study [44].

\section{The dual POD-like and CAT-like activity of NPPLGA}

In our previous work, the POD-like activity and steady-state kinetics of $N P_{P L G A}$ were studied in detail [44]. The CAT-like performance of $N P_{P L G A}$ was evaluated by CAT assessment kit conforming to the protocols of the manufacturer. In brief, $10 \mu \mathrm{L}$ of $N P_{P L G A}$ solution $\left(1 \mathrm{mg} \mathrm{mL} \mathrm{m}^{-1}\right)$ or CAT solution ( $1 \mathrm{mg} \mathrm{mL}^{-1}$ ) was added to $50 \mu \mathrm{L}$ buffer (T-S buffer, $33 \mathrm{mM}$ phosphoric acid, $33 \mathrm{mM}$ citric acid, $23 \mathrm{mM}$ boric acid, $\mathrm{pH}$ 7.0) when $\mathrm{H}_{2} \mathrm{O}_{2}$ is available at different concentrations. After 5 min of reaction, the dilution of residual $\mathrm{H}_{2} \mathrm{O}_{2}$ was performed 50 times with T-S buffer solution and detected with $520 \mathrm{~nm}$ UV-VIS spectrophotometer (UV-1000, Shanghai, China). The kinetic parameters of $N P_{P L G A}$ were assessed utilizing the following the plot of Lineweaver-Burk (a):

$$
\frac{1}{V}=\frac{1}{V_{\max }}+\frac{K_{m}}{\left(V_{\max } S\right)}
$$

Where $V$ states the primary velocity, $V_{\max }$ represents the maximum velocity of reaction, $S$ represents the concentration of the substrate, and $K_{\mathrm{m}}$ states the constant of Michaelis-Menten, which is equal to the concentration of substrate at which the conversion rate is half of $V_{\max }$ and represents the enzyme affinity [45]. $V_{\max }$ was measured as the molar alternation by the absorbance of UV 
based on the following Eq. (b):

$$
A=\varepsilon l c \quad(b)
$$

Further, $A$ represent the absorbance, $\varepsilon$ shows the coefficient of absorbance, $l$ shows the distance length, and c represents the molar concentration with $\varepsilon=3.9 \times 10^{4} M^{-1} \mathrm{~cm}^{-1}$ and $l=10 \mathrm{~mm}$ [46].

\section{DOX loading and determination of encapsulation efficiency}

$500 \mu \mathrm{L}$ of solution of DOX $\left(2 \mathrm{mg} \mathrm{mL}^{-1}\right)$ was blended with $1000 \mu \mathrm{L}$ of $N P_{P L G A}$ solution $(1 \mathrm{mg}$ $\mathrm{mL}^{-1}$ ), well-stirred for $1 \mathrm{~h}$, and then rinsed three times with deionized (DI) water. The loading of DOX content was determined utilizing a UV-VIS spectrophotometer (UV-1000, Shanghai, China) with the absorbance at $480 \mathrm{~nm}$. The content of drug loading was determined as the amount of loaded drug $(\mathrm{mg})$ for every $100 \mathrm{mg}$ of polymeric nanoparticles, whilst the efficiency of encapsulation was determined through the encapsulated ratio of drug to the primary amount of drug.

$$
\begin{gathered}
\text { Loading content (\%) }=\frac{W_{t}}{W_{s}} \times 100 \% \\
\text { Encapsulation efficiency }(\%)=\frac{W_{t}}{W_{o}} \times 100 \%
\end{gathered}
$$

Where $W_{\mathrm{t}}$ shows the weight of DOX in $N P_{P L G A}, W_{\mathrm{s}}$ states the weight of $N P_{P L G A}$, and $W_{0}$ represents the primary weight of DOX in the procedure.

\section{Cell culture and cytotoxicity assessment}

The lung adenocarcinoma A549 cells were routinely cultured in an RPMI-1640 medium including 
$1 \%$ streptomycin $\left(100 \mu \mathrm{gL}^{-1}\right), 1 \%$ penicillin $\left(100 \mathrm{U} \mathrm{mL}^{-1}\right)$ and $10 \%$ heat-inactivated $\mathrm{FBS}$, in a humidified incubator at $37{ }^{\circ} \mathrm{C}$ with an atmosphere of $95 \%$ air and $5 \% \mathrm{CO}_{2}$. The cells were typically passaged at a ratio of 1:3 every 3 days to retain the growth stage exponentially.

After A549 cells reached the exponential growth stage, the cells were harvested to provide cell suspension. Subsequently, the cells were inoculated into microwell containing 96-well with a density of 8,000 cells per well. After $12 \mathrm{~h}$ of incubation, the cells were processed with $N P_{P L G A}$ at various concentrations $\left(50,100,200\right.$, and $\left.400 \mu \mathrm{g} \cdot \mathrm{mL}^{-1}\right)$. After $12 \mathrm{~h}$ of co-incubation, $20 \mu \mathrm{L}$ MTT

solution $\left(5 \mathrm{mg} \cdot \mathrm{mL}^{-1}\right)$ was added to the wells. Following $4 \mathrm{~h}$ of incubation, the culture media was taken out and the dissolution of formed formazan in $150 \mu \mathrm{L}$ of DMSO was performed. The microwell plate was incubated for 15 min again. At last, the wells absorbance was assessed at 490 nm with a microporous plate spectrophotometer (Infinite F200, Tecan Group Ltd., Switzerland).

MTT assessment was performed to detect the effect of $N P_{P L G A}$ on oxidative damage of A549 cells under different $\mathrm{pH}$ conditions induced by $\mathrm{H}_{2} \mathrm{O}_{2}$. Briefly, A549 cells were cultured for $24 \mathrm{~h}$ in a different medium $\left(\mathrm{pH} 7.4\right.$ or $\mathrm{pH}$ 6.0) and then treated with various concentrations of $N P_{P L G A}(50$, $100,200,400 \mu \mathrm{g} \cdot \mathrm{mL}^{-1}$ ) in A549 cells for $12 \mathrm{~h}$. The medium was then eliminated, rinsed with PBS once, continued with the addition of $1 \mathrm{mM}$ or $5 \mathrm{mM} \mathrm{H}_{2} \mathrm{O}_{2}$. The cells were then incubated for 30 min at $37{ }^{\circ} \mathrm{C}$ containing $5 \% \mathrm{CO}_{2}$. The viability of the treated cells was specified through MTT assessment. Additionally, MTT was used to evaluate the $\mathrm{H}_{2} \mathrm{O}_{2}$-induced oxidative damage within A549 cells using different formulation treatments.

\section{Analysis the levels of intracellular ROS}

The levels of ROS in A549 cells treated with different formulations were determined using the ROS 
test kit following the protocols of manufacturer. A549 cells were first processed for $12 \mathrm{~h}$ with 200 $\mu \mathrm{g} \cdot \mathrm{mL}^{-1} N P_{P L G A}$, and then rinsed with PBS and incubated for $15 \mathrm{~min}$ with $50 \mu \mathrm{M}$ DCFH-DA in FBS-free RPMI 1640 media at $37{ }^{\circ} \mathrm{C}$ in the dark. Further, after the cells were rinsed two times with PBS, the group cultured in the medium at $\mathrm{PH} 7.4$ was treated for 20 min with $5 \mathrm{mM} \mathrm{H}_{2} \mathrm{O}_{2}$, and the group cultured in the medium at $\mathrm{pH} 6.0$ was treatment with $1 \mathrm{mM} \mathrm{H}_{2} \mathrm{O}_{2}$ for $10 \mathrm{~min}$. The cells were washed again, and the levels of intracellular ROS were evaluated via the microscope of inverted fluorescence (Eclipse TE 2000-U) supplied with a high-resolution CCD camera (CVS3200).

\section{Detection of GSH in the treated A549 cells}

A549 cells were implanted in a cultrue plate containing 6 wells at a cell density of $1 \times 10^{6}$ cells per well and incubated for at $37{ }^{\circ} \mathrm{C} 12 \mathrm{~h}$. Subsequently, $200 \mu \mathrm{g} / \mathrm{mL} N P_{P L G A}$ or $100 \mu \mathrm{g} / \mathrm{mL}$ DOX-NPPLA was used for treating the cells and procedure continued by for $12 \mathrm{~h}$ of incubation in an acidic medium. Later, $1 \mathrm{mM} \mathrm{H}_{2} \mathrm{O}_{2}$ was added for another 10 min of incubation. The treated cells were then gathered and rinsed with PBS for three times, and then resuspended in PBS by adding the triple volume of the cell pellet. After 3 times of freezing and thawing, the cells were centrifuged for 10 min at $8000 \mathrm{~g}$, and the supernatant was gathered at $4{ }^{\circ} \mathrm{C}$. Subsequently, the supernatant was detected using a reduced GSH kit according to the manufacturers' instructions. The absorbances at $450 \mathrm{~nm}$ were detected immediately utilizing the spectrophotometer (Infinite F200, Tecan Group Ltd., Switzerland).

\section{Apoptosis assessment}

To assess the apoptotic cells, A549 cells processed with different formulations were stained with the solution of Hoechst H33258 (2 $\left.\mu \mathrm{g} \mathrm{mL}^{-1}\right)$ at room temperature (RT) for $10 \mathrm{~min}$. The stained cells 
were observed using an inverted fluorescence microscope, and unprocessed A549 cells utilized as the control.

Apoptosis was quantitatively evaluated by the assessment kit of Annexin V-FITC apoptosis (Keygen Biotech, Nanjing, China). The Annexin V-FITC-PI double labeling was conducted conforming to the kit manual of manufacturer. The A549 cells processed with different formulations were gathered and rinsed with PBS. Later, the staining of $1 \times 10^{6}$ cells were performed by $5 \mu \mathrm{L}$ Annexin V-FITC and $5 \mu \mathrm{L}$ PI in a $500 \mu \mathrm{L}$ buffer of binding at RT for 15 min in the dark. Finally, the apoptotic cells were determined via flow cytometer of FACS Calibur (BD Biosciences, San Jose, CA) using untreated A549 cells as the control.

\section{Results and discussion}

\section{Characterization of $N P$ PLGA}

The core-shell structure of $N P$ PLGA can ensure the dispersion stability of $\gamma$ - $\mathrm{Fe}_{2} \mathrm{O}_{3} \mathrm{NPs}$, enhance its enzyme-like activity (Fig. 1A), and improve the bio-compatibility of $N P_{\mathrm{PLGA}}$ for further intracellular application. The structure and morphology of the $\gamma-\mathrm{Fe}_{2} \mathrm{O}_{3}$ NPs and $N P$ PLGA were characterized employing the Fourier-transform infrared spectrum (FT-IR), transmission electron microscope (TEM), and X-ray diffractometer (XRD). The details can be found in our previous study [44]. The TEM images illustrated that the prepared nanoscale $\gamma-\mathrm{Fe}_{2} \mathrm{O}_{3}$ NPs had uniform morphology, the diameter range was 10-15 nm [44], and the $N P_{\text {PLGA }}$ exhibited a mono-dispersed sphere with a 40-50 nm uniform size (Fig. 1B). Moreover, the XRD data demonstrated that the crystalline properties and the peaks conform to the standard $\gamma-\mathrm{Fe}_{2} \mathrm{O}_{3}$ reflection, but the $\alpha-\mathrm{Fe}_{2} \mathrm{O}_{3}$ phase was not observed. Furthermore, these $\gamma-\mathrm{Fe}_{2} \mathrm{O}_{3}$ NPs were successfully modified by PLGA according to the FT-IR data 
[44].

(A)

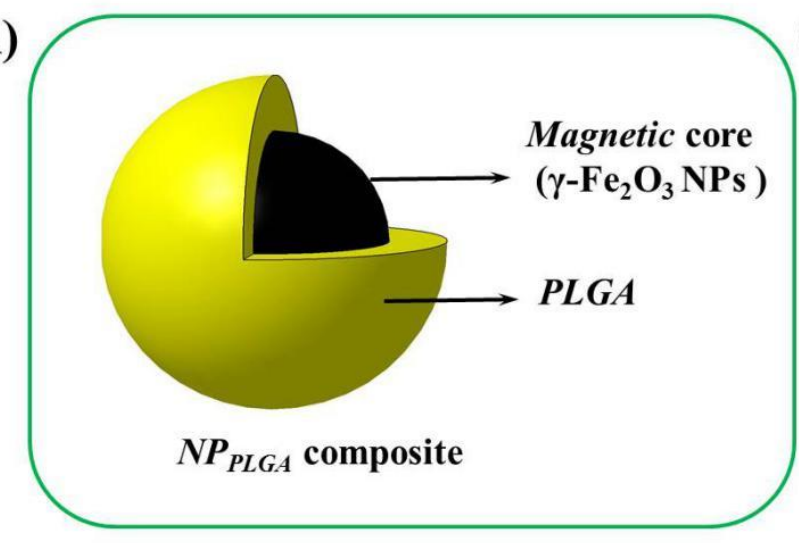

(B)

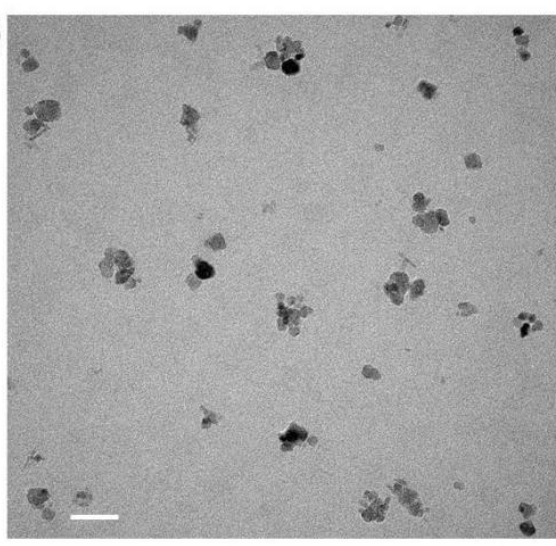

(C)

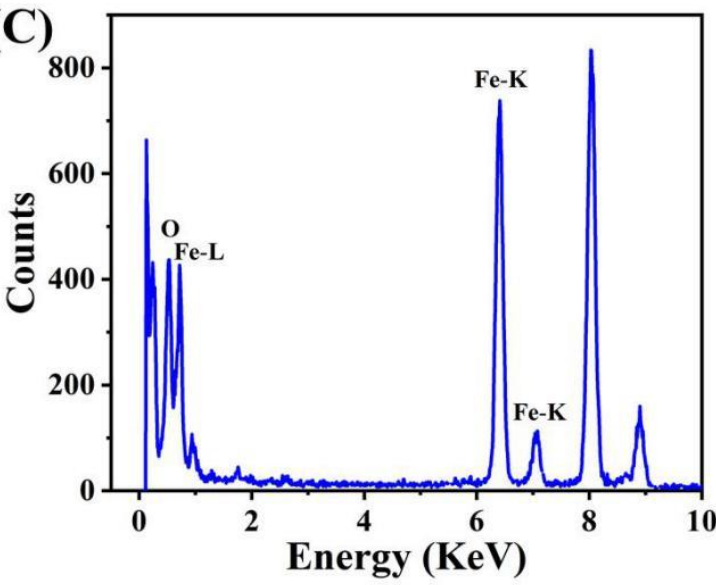

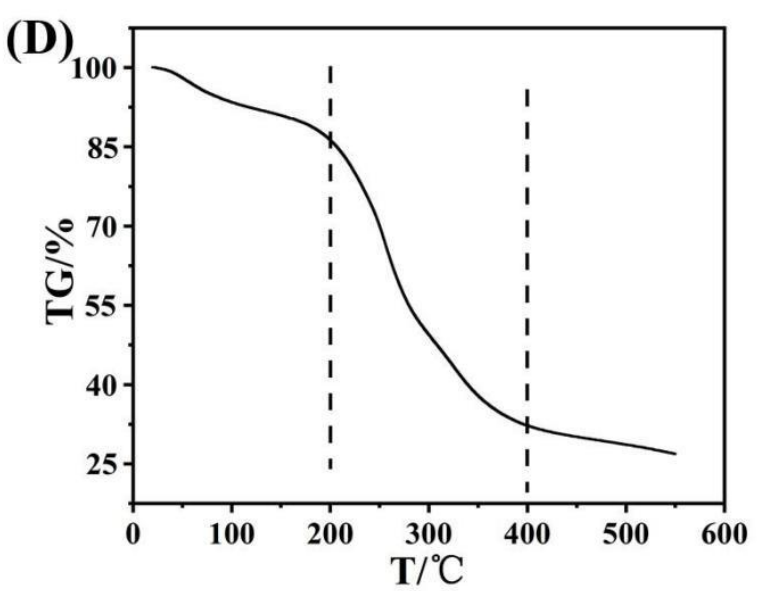

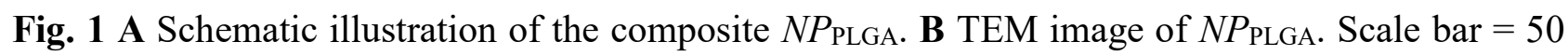
nm. C EDS spectrum of $N P_{\text {PLGA. }}$ D Thermogravimetric curve of $N P_{\text {PLGA. }}$.

To accurately analyze the elements of the $N P_{\text {PLGA }}$, EDS spectroscopy characterization was performed to confirm the presence of $\mathrm{O}$ and $\mathrm{Fe}$ (Fig. 1C). Thermogravimetric analysis was used to determine the change of $N P_{P L G A}$ mass with temperature increase. The results showed that the weight loss of $N P_{P L G A}$ was severe at $200-400^{\circ} \mathrm{C}$, nearly $70 \%$ at $400^{\circ} \mathrm{C}$, and stable at $550^{\circ} \mathrm{C}$ at about $28.8 \%$ (Fig. 1D). 
(A)

(B)
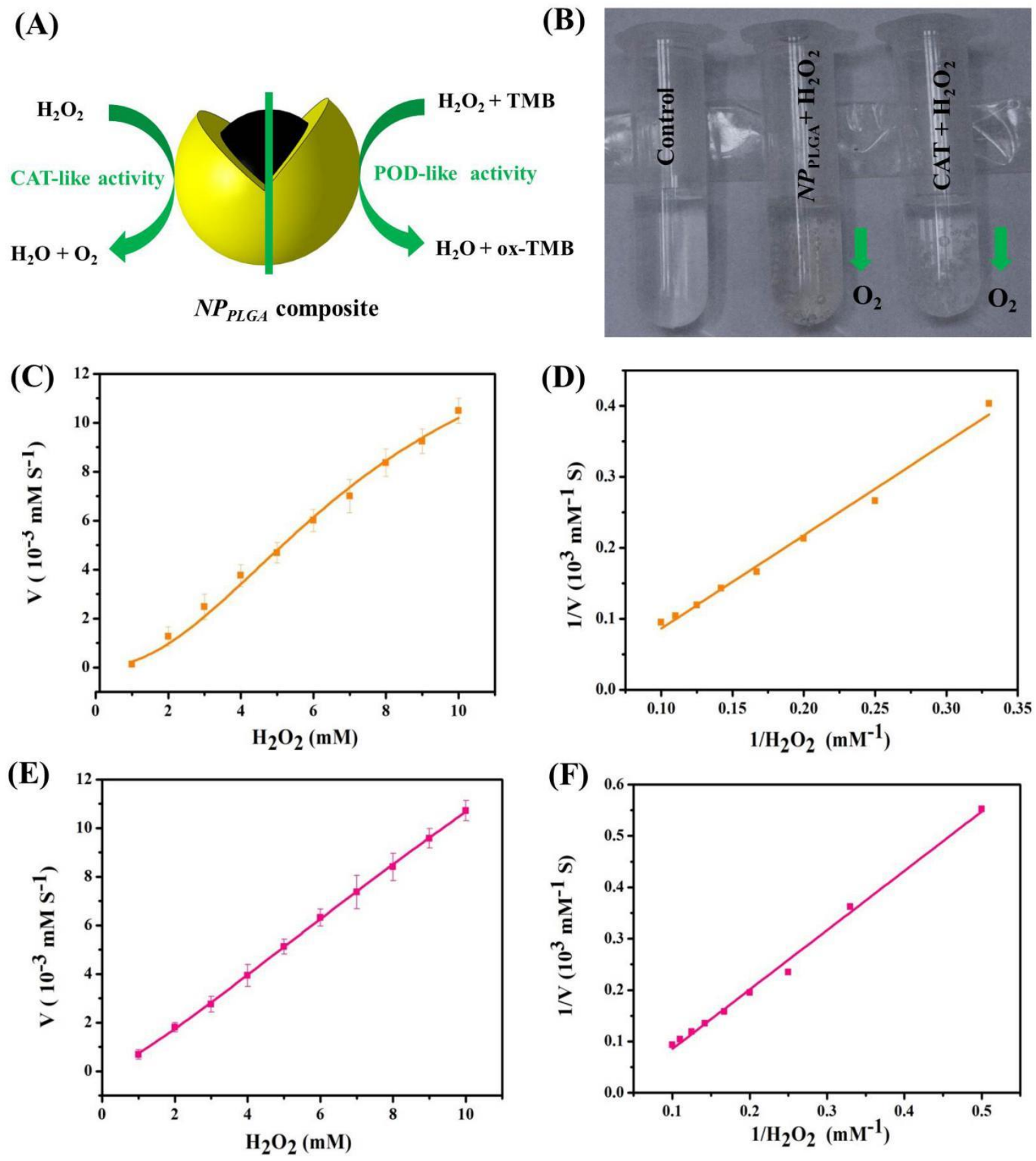

Fig. 2 A Schematic illustration for dual enzyme-like catalytic performance of the $N P_{\text {PLGA }}$. B CAT-like activity assay of $N P_{P L G A}$, both $N P_{P L G A}$ and natural CAT can catalyze $\mathrm{H}_{2} \mathrm{O}_{2}$ to produce $\mathrm{O}_{2}$ when $\mathrm{H}_{2} \mathrm{O}_{2}$ is available in the system. C Steady-state Kinetic assays for $N P_{P L G A}$ in the presence of $\mathrm{H}_{2} \mathrm{O}_{2}$, and D corresponding double-reciprocal plot. E) Kinetic assays of natural CAT in the presence of $\mathrm{H}_{2} \mathrm{O}_{2}$, and $\mathrm{F}$ ) corresponding double-reciprocal plot. 
The POD-like activity and steady-state kinetic parameters of the $N P_{\text {PLGA }}$ for TMB oxidation were studied in detail as we did previously [44]. The maximum primary velocity $\left(V_{\max }\right)$ and the contant of Michaelis-Menten $\left(K_{m}\right)$ were measured utilizing the Lineweaver-Burk plot of the double reciprocal line related to the equation of the Michaelis-Menten. Kinetic analysis showed that $N P_{\text {PLGA }}\left(K_{m}=0.9\right)$ had a greater affinity for TMB compared to POD $\left(K_{m}=1.98\right)$ at acidic $\mathrm{pH}$ [44]. Furthermore, the outcomes revealed that for $\mathrm{H}_{2} \mathrm{O}_{2}$, the $K_{m}$ value of $N P_{\text {PLGA }}\left(K_{m}=4.41\right)$ was greater than POD $\left(K_{m}=0.30\right)$, proposing that $N P P L G A$ needed a higher concentration of $\mathrm{H}_{2} \mathrm{O}_{2}$ to describe the same POD activity as natural POD.

We further examined the CAT-like activity of $N P_{\text {PLGA. }}$ As shown in the Fig. $2 \mathrm{~B}$, it is obvious that $\mathrm{O}_{2}$ was produced in the $N P P L G A$ and natural CAT groups when $\mathrm{H}_{2} \mathrm{O}_{2}$ is available, exhibiting that both $N P_{P L G A}$ and natural CAT is able to catalyze $\mathrm{H}_{2} \mathrm{O}_{2}$ to create $\mathrm{O}_{2}$. In order to measure the enzyme parameters, we investigated the steady-state kinetics of $N P_{P L G A}$ through calculating the primary rates as a function of the concentration of $\mathrm{H}_{2} \mathrm{O}_{2}$. The catalytic procedure followed the normal Michiaelis-Menten reaction, and the Lineweaver-Burk diagram was shown in Fig. 2(C-F). As can be seen from Table 1 , the $K_{\mathrm{m}}$ values of $N P_{P L G A}$ and natural CAT were $0.76 \mathrm{mM}$ and $0.86 \mathrm{mM}$, suggesting a high affinity of $N P_{P L G A}$ to $\mathrm{H}_{2} \mathrm{O}_{2}$.

Table. 1 Michaelis-Menten $\left(K_{m}\right)$ and maximum reaction velocity $\left(V_{\max }\right)$

\begin{tabular}{cccc}
\hline Enzyme & Substrate & $\boldsymbol{K}_{\boldsymbol{m}}(\mathbf{m M})$ & $\boldsymbol{V}_{\boldsymbol{m a x}}\left(\mathbf{1 0}^{\mathbf{- 3}} \mathbf{m} \mathbf{M ~ s}^{\mathbf{- 1}}\right)$ \\
\hline Catalase (CAT) & $\mathrm{H}_{2} \mathrm{O}_{2}$ & 0.86 & 33.53 \\
$N P_{\text {PLGA }}$ & $\mathrm{H}_{2} \mathrm{O}_{2}$ & 0.76 & 22.32 \\
\hline
\end{tabular}




\section{Effect of CAT-like activity of $\mathrm{NP} P$ LGA on $\mathrm{H}_{2} \mathrm{O}_{2}$-induced cellular oxidative damage}

We first evaluated the cytotoxicity of $N P_{P L G A}$ to A549 cells by MTT assay, and A549 cells were processed for $24 \mathrm{~h}$ with various concentrations of $N P_{P L G A}$. The results indicated the processed A549 cells still maintained a high survival rate even when the concentration of $N P_{P L G A}$ reached 400 $\mu \mathrm{g} \cdot \mathrm{mL}^{-1}$, indicating that $N P_{P L G A}$ possessed a minor impact on the ability of A549 cell proliferation (Fig. 3A).

$\mathrm{H}_{2} \mathrm{O}_{2}$ is a common ROS produced in cellular metabolism, and CAT and POD have progressed to preserve cells against oxidative damage induced by $\mathrm{H}_{2} \mathrm{O}_{2}$ [47]. This study speculated that $N P_{P L G A}$ with CAT-like activity had a protective effect on human lung cancer A549 cells against against oxidative damage induced by $\mathrm{H}_{2} \mathrm{O}_{2}$. MTT assessment was utilized to study the effect of $N P_{P L G A}$ at different concentrations and $5 \mathrm{mM} \mathrm{H}_{2} \mathrm{O}_{2}$ on $\mathrm{H}_{2} \mathrm{O}_{2}$-induced oxidative damage of A549 cells in neutral TME. The results indicated that the rate of survival for A549 cells increased with the increase of $N P_{P L G A}$ concentration (Fig. 3A). In addition, we further confirmed the effect of $N P_{P L G A}$ on $\mathrm{H}_{2} \mathrm{O}_{2}$-induced oxidative damage of A549 cells with various treatments (Fig. 3B). The results suggested that the A549 cells co-treated with $N P_{P L G A}$ and $\mathrm{H}_{2} \mathrm{O}_{2}$ displayed higher viability than those treated with $\mathrm{H}_{2} \mathrm{O}_{2}$ alone. This is because $N P P L G A$ could decompose $\mathrm{H}_{2} \mathrm{O}_{2}$ to generate $\mathrm{H}_{2} \mathrm{O}$ and $\mathrm{O}_{2}$ under neutral TME conditions, thereby reducing the toxicity and side effects on cells. 

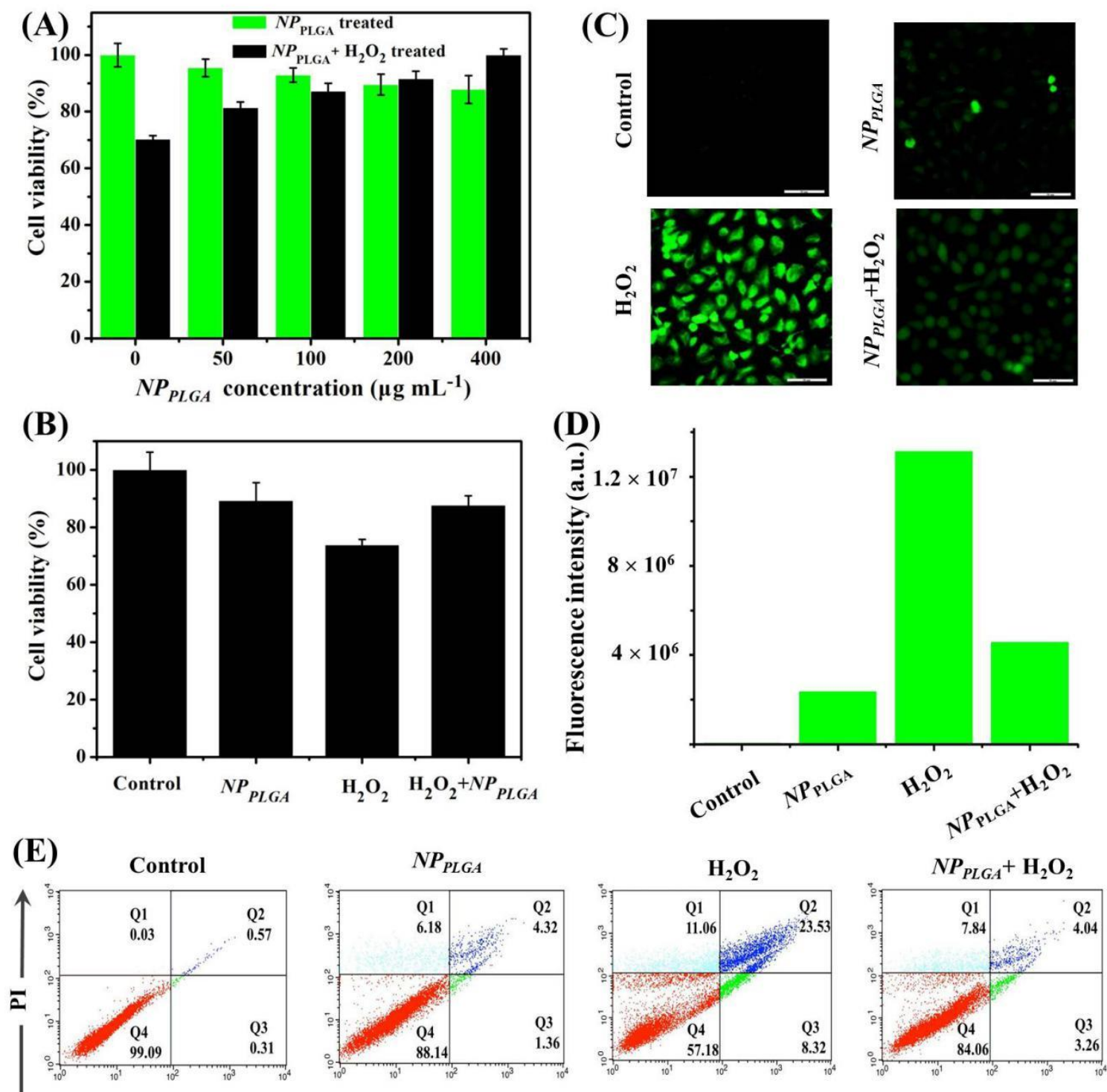

Annexin V-FITC

Fig. 3 A Cytotoxicity of $N P_{P L G A}$ and $\mathrm{H}_{2} \mathrm{O}_{2}$-induced oxidative damage assays of treated A549 cells with various concentration of $N P_{P L G A}$ including $50,100,200,400 \mu \mathrm{g} \cdot \mathrm{mL}^{-1}$, and the cells were treated with various concentration $N P_{P L G A}$ and $5 \mathrm{mM} \mathrm{H}_{2} \mathrm{O}_{2}$ under neutral TME conditions (pH 7.4). B $\mathrm{H}_{2} \mathrm{O}_{2}$-induced oxidative damage of A549 cells with different formulation treatments, the cells were treated for $12 \mathrm{~h}$, and the concentration of $N P_{P L G A}$ was $200 \mu \mathrm{g} \cdot \mathrm{mL}^{-1}$. C Assays of ROS production in treated A549 cells for $12 \mathrm{~h}$ with different formulations, and D corresponding statistical of the fluorescence intensity analysis in the processed cells. E Apoptosis assays of the 
processed A549 cells with different treatment through flow cytometry utilizing the staining methods of fluorescein Annexin V-FITC-PI double labeling, untreated A549 cells employed as a control. Early apoptosis (bottom right), late apoptosis (upper right), necrotic cells (upper left), and normal cells (bottom left).

We used a ROS fluorescence probe DCFH-DA to determine the intracellular ROS level. As shown in Figs. 3C and 3D, only weak green fluorescence was observed in the A549 cells treated with $N P_{P L G A}$. In contrast, bright green fluorescence signals was displayed in $\mathrm{H}_{2} \mathrm{O}_{2}$-processed cells, indicating upper intracellular ROS levels. However, cells treated with $N P_{P L G A}$ and $\mathrm{H}_{2} \mathrm{O}_{2}$ showed relatively weak emission. These results illustrated that $N P_{P L G A}$ was able to decompose $\mathrm{H}_{2} \mathrm{O}_{2}$, thus reducing the oxidative damage induced by $\mathrm{H}_{2} \mathrm{O}_{2}$. Furthermore, to survey the influence of $\mathrm{H}_{2} \mathrm{O}_{2}$-induced oxidative damage of $N P_{P L G A}$ on the apoptosis of A549, flow cytometry was utilized to quantitatively evaluate the apoptosis level. It was displayed in the Fig. 3E, the number of normal cells reached about $90 \%$ after incubation for $12 \mathrm{~h}$ with $200 \mu \mathrm{g} \cdot \mathrm{mL}^{-1} N P_{P L G A}$, indicating that the cytotoxicity of $N P_{P L G A}$ could be negligible. After treatment with $5 \mathrm{mM} \mathrm{H}_{2} \mathrm{O}_{2}$ for 20 min, more than half of A549 cells died. However, after treatment with $N P P L G A$ and $\mathrm{H}_{2} \mathrm{O}_{2}$ for $12 \mathrm{~h}$, the cell activity was significantly enhanced, while the number of normal cells only increased to more than $80 \%$. These results further confirmed that $N P_{P L G A}$ could reduce the oxidative damage induced by $\mathrm{H}_{2} \mathrm{O}_{2}$.

\section{Synergistic effect of POD-like activity of NPPLGA combined with DOX on A549 cells}

We first evaluated the sensitivity for A549 cells utilizing colorimetry based the POD-like activity of $N P_{P L G A}$. Various numbers of A549 cells $\left(1 \sim 8 \times 10^{3}\right.$ cells $)$ were processed by using $200 \mu \mathrm{g} \cdot \mathrm{mL}^{-1}$ of NP $P_{\text {PLGA }}$. The sediments were gathered and washed three times by PBS to eliminate the unabsorbed 
$N P_{P L G A}$. When TMB and $\mathrm{H}_{2} \mathrm{O}_{2}$ were available in the studied system, the absorbed $N P_{P L G A}$ could catalyze a color reaction that could be discerned by bare eyes and be quantitatively detected the absorbance at $652 \mathrm{~nm}$. When the number of A549 cells raised, the formation of TMB oxidation products changed rapidly, suggesting that more $N P_{P L G A}$ were absorbed by A549 cells. Utilizing this waytechnique, few cells of about $1 \times 10^{3}$ A549 could be detected (Figs. 4A and 4B).

(A)
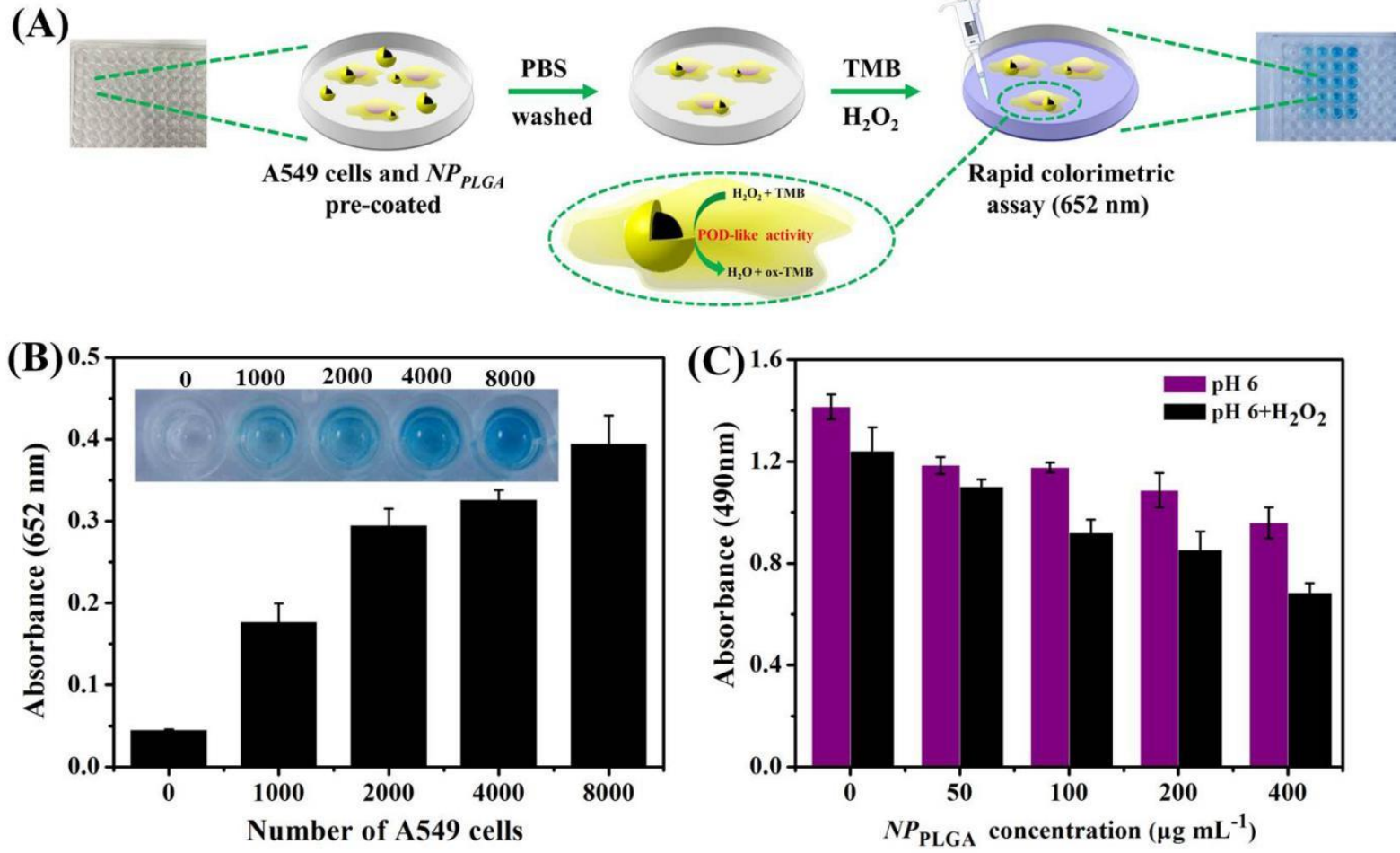

Fig. 4 A Schematic illustrated the process of quantitative colorimetric assay of A549 cells via the POD-like performance of $N P_{P L G A}$, and B A549 cells were detected based on the POD-like activity of $N P_{P L G A}$ in the presence of TMB. Inset: indicates the change of the color related to the various number of A549 cells. C The concentration-dependent cytotoxicity assay of $N P_{P L G A}$ in acidic TME.

Furthermore, the cytotoxicity of $N P_{P L G A}$ to A549 cells was determined by MTT assay under acidic TME conditions. In comparison with the $N P_{P L G A}$ treatment, the survival fraction of cells after $\mathrm{H}_{2} \mathrm{O}_{2}$ treatment under acid TME was significantly reduced (Fig. 4C). The results show that $N P_{P L G A}$ 
decomposed $\mathrm{H}_{2} \mathrm{O}_{2}$ to form $\bullet \mathrm{OH}$ under the mild acidic TME of $\mathrm{pH}$ 6.0, triggering the production of ROS and further enhancing the toxic effect of $\mathrm{H}_{2} \mathrm{O}_{2}$ on cells.

To assess the intracellular $\bullet \mathrm{OH}$ production, a ROS fluorescence probe DCFH-DA was employed to estimate the intracellular ROS level. Under the acidic TME, the fluorescence of A549 cells was negligible after co-incubation with $N P_{P L G A}$ or DOX-NPPLGA. In contrast, A549 cells treated with $N P_{P L G A}$ under $\mathrm{H}_{2} \mathrm{O}_{2}$ displayed strong green fluorescence compared, while cells treated with combined DOX-NPPLGA and $\mathrm{H}_{2} \mathrm{O}_{2}$ were shown a much stronger green fluorescence (Figs. $5 \mathrm{~A}$ and B), implying that under the weak acidic TME condition, DOX-NPPLGA and $\mathrm{H}_{2} \mathrm{O}_{2}$ generated a great quantity of ROS in the cells.
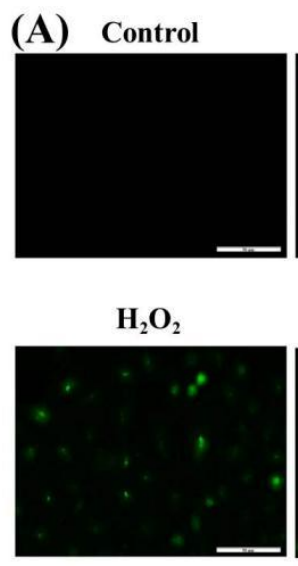

(B)

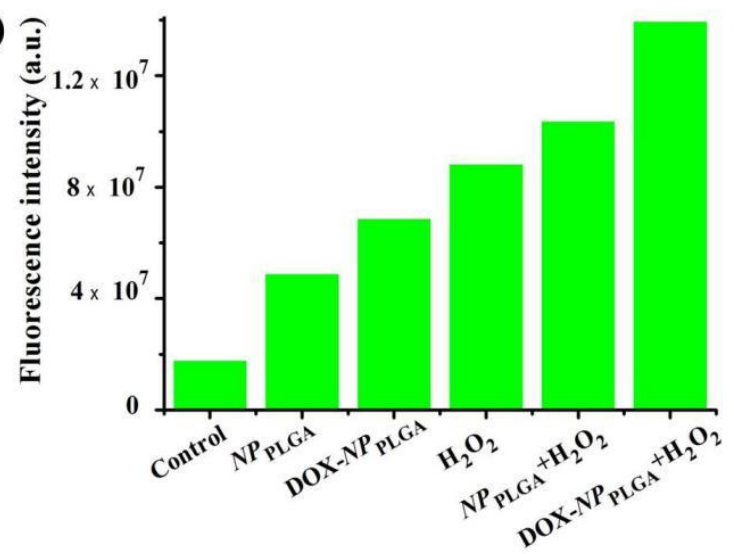

$N P_{\text {PLGA }}$

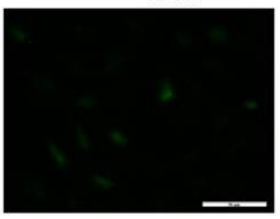

$N P_{\mathrm{PLGA}}+\mathrm{H}_{2} \mathrm{O}_{2}$

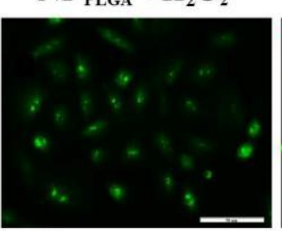

DOX-NP $P_{\mathrm{PLGA}}+\mathrm{H}_{2} \mathrm{O}_{2}$

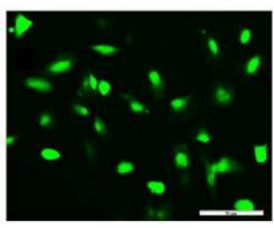

(C)

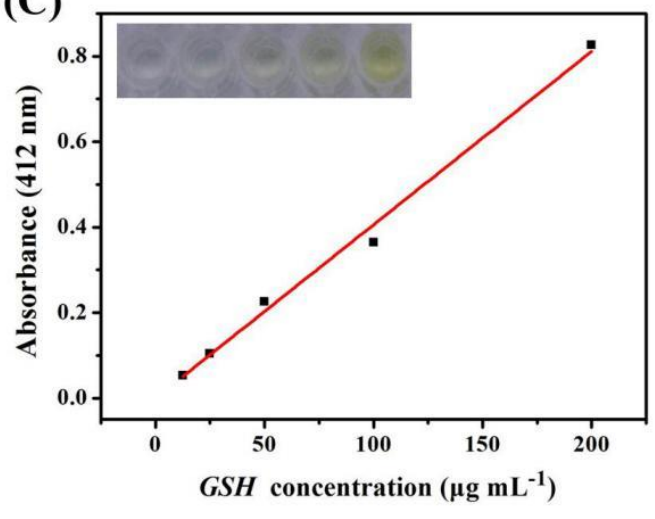

(D)

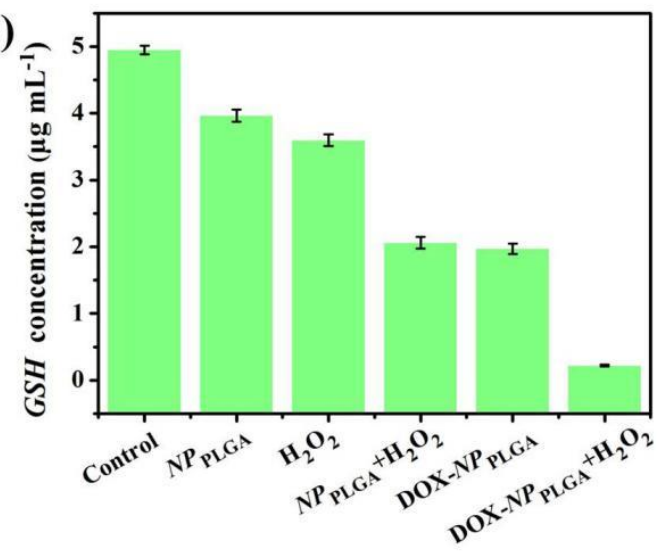

Fig. 5 A Assay of intracellular ROS level, fluorescence images of A549 cells after co-incubation with different formulations for $12 \mathrm{~h}$, and stained using ROS fluorescence probe DCFH-DA, and B 
corresponding fluorescence intensity analysis. Scale bars $=100 \mu \mathrm{m}$. C A dose-dependent linear curve of various concentrations of GSH solutions with the optimum models, and as well as the inserted photos is the photograph of different concentration. D Assay of reduced GSH in the treated A549 cells with different formulations.

GSH protects normal immune system and tissue cells from oxidative damage [48]. Therefore, GSH is an important indicator for studying the effects of ROS, free radicals, and oxides on cells [49]. The results showed that $\mathrm{H}_{2} \mathrm{O}_{2}, N P_{P L G A}, N P_{P L G A}+\mathrm{H}_{2} \mathrm{O}_{2}$ and DOX-NPPLGA treatment groups all consumed the reduced GSH to varying degrees (Fig. 5D). Moreover, this phenomenon is even more obvious in the DOX-NPPLGA and $\mathrm{H}_{2} \mathrm{O}_{2}$ co-treated group. These results indicated that the $N P_{P L G A}$ in collaboration with the antineoplastic DOX can significantly consume the reduced GSH in A549 cells, making the tumor cells unable to repair the external oxidative damage, thus increasing the cell death.

We also examined the effect of various concentration DOX-NPPLGA on the cell viability related to the treated A549 cells. According to the Fig. 6A, the cell viability of A549 cells decreased with the rising DOX-NPPLGA concentration. Furthermore, the cell viability of A549 cells processed via $N P_{P L G A}$ was much higher than that of the group treated with $N P_{P L G A}$ and $\mathrm{H}_{2} \mathrm{O}_{2}$, and the cell survival rate of A549 cells treated with DOX-NPPLGA and $\mathrm{H}_{2} \mathrm{O}_{2}$ was significantly more mitigated compared to the group treated with DOX-NPPLGA (Fig. 6B). These results indicated that the anti-tumor drug DOX could enhance the oxidative damage of $N P_{P L G A}$ to A549 cells under acidic TME conditions, and the combination of the POD-like activity of $N P_{P L G A}$ with DOX could produce a synergistic anti-tumor effect on A549 cells. 

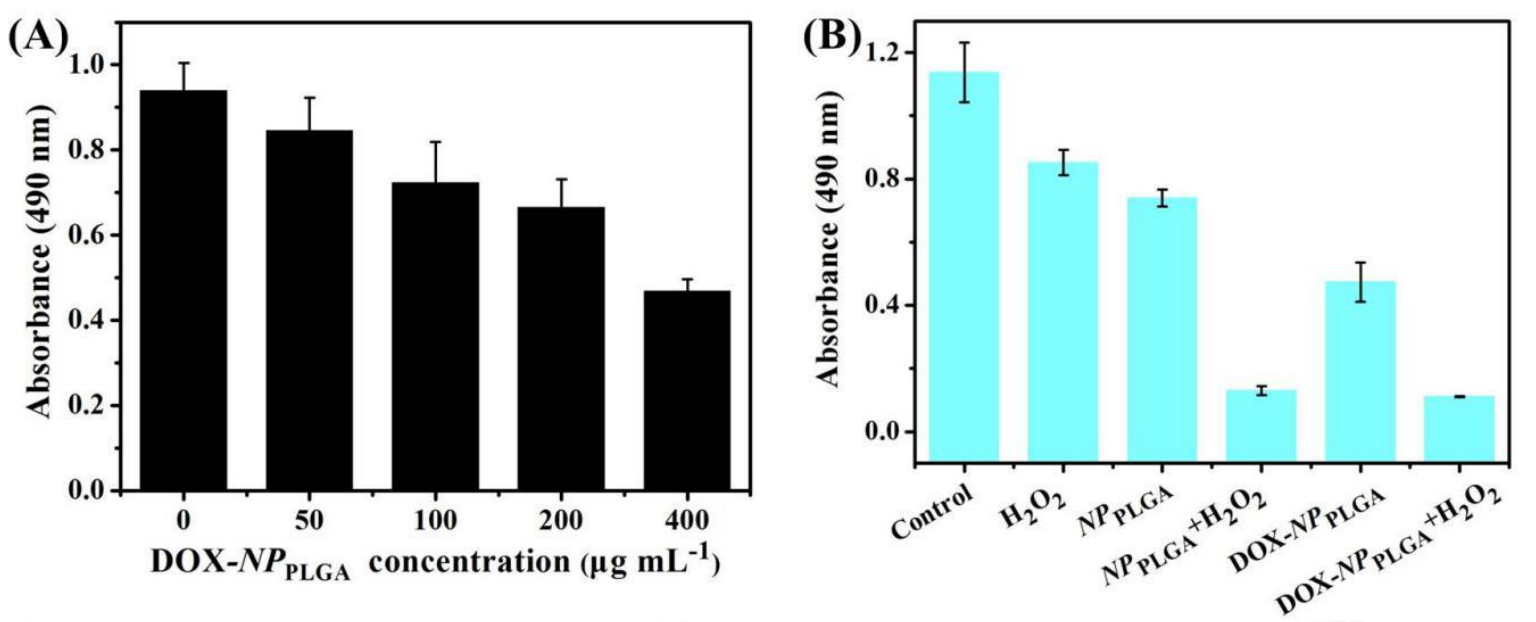
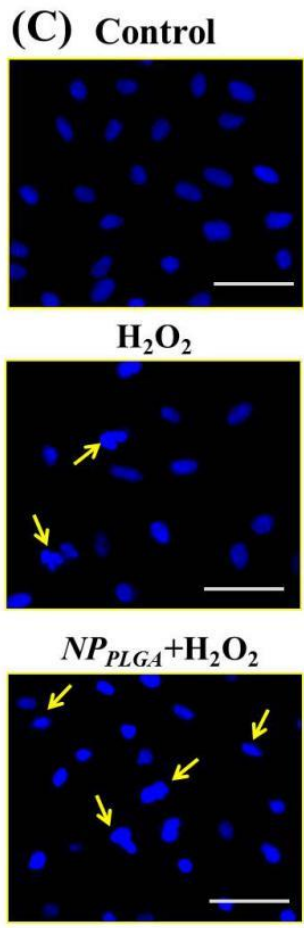

$N P_{P L G A}$

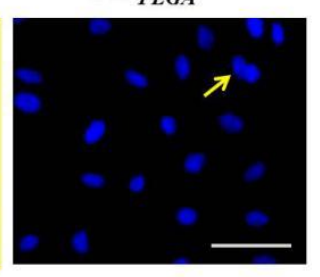

DOX-NP $P_{P L G A}$

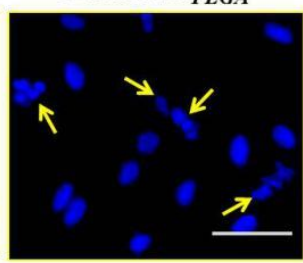

DOX-NP $P_{P L G A}+\mathrm{H}_{2} \mathrm{O}_{2}$

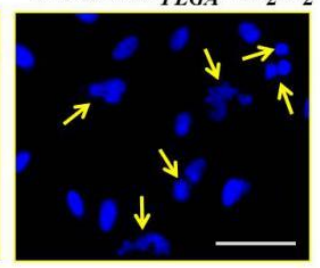

(D).
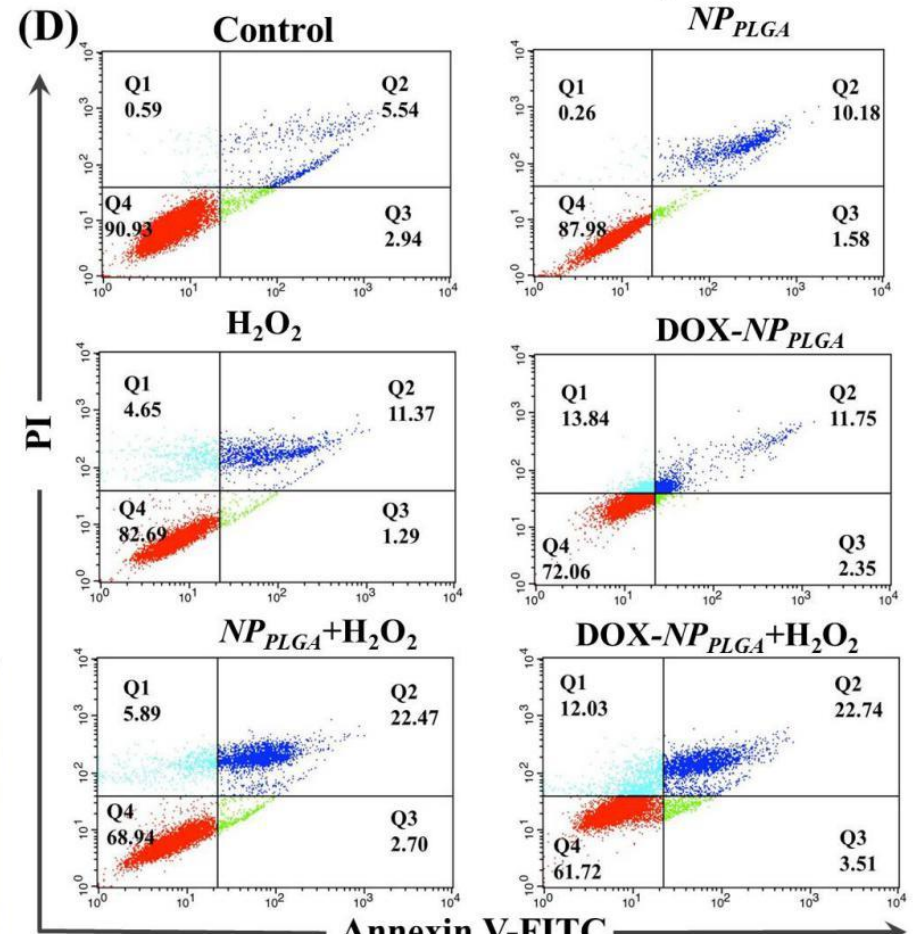

Fig. 6 A Effect of various concentration of DOX-NPPLGA on survival rate of the treated A549 cells. B Effect of different formulations on the cell viability of the treated A549. C The A549 cells with different formulation treatment under acidic TME ( $\mathrm{pH}$ 6.0) were stained via Hoechst H33258. Scale bars $=100 \mu \mathrm{m}$. D Apoptosis assay of the A549 cells with different treatments through flow cytometry by double labeling staining of fluoresce Annexin V-FITC-PI, under acidic TME ( $\mathrm{pH}$ 6.0). Untreated A549 cells employed as control.

To observe the apoptotic cells' nuclear division, the processed A549 cells were stained with the 
fluorescent dye Hoechst H33258, which could combine with the AT-rich zone of DNA to analyze the DNA of apoptotic cells relatively quantitatively [50]. The results showed that when A549 cells were co-treated with DOX-NPPLGA and $\mathrm{H}_{2} \mathrm{O}_{2}$, the alterations including nuclear peripheral accumulation, chromatin condensation, and nuclear segmentation were considerably greater than those in other groups (Fig. 6C).

In order to further investigate the apoptosis mechanism, flow cytometry was used to quantitatively examination the apoptosis level of the processed A549 cells. The A549 cells were incubated with different formulations including $\mathrm{H}_{2} \mathrm{O}_{2}, N P_{P L G A}, N P_{P L G A}+\mathrm{H}_{2} \mathrm{O}_{2}, D O X-N P_{P L G A}$ and DOX-NPPLGA $+\mathrm{H}_{2} \mathrm{O}_{2}$ under acidic TME conditions ( $\mathrm{pH}$ 6.0). The number of cells in each quadrant was quantitatively analyzed. The results showed the apoptosis of A549 cells processed with $N P_{P L G A}$ $+\mathrm{H}_{2} \mathrm{O}_{2}$ was more obvious compared to the $\mathrm{H}_{2} \mathrm{O}_{2}$ group, and while the apoptosis of A549 cells with combined DOX-NPPLGA $+\mathrm{H}_{2} \mathrm{O}_{2}$ treatment was much more obvious, indicating that the A549 cells produced extra high toxicity $\bullet \mathrm{OH}$ (Fig. 6D). These results also indicated that nanozyme activity of $N P_{P L G A}$ together with anti-tumor drug DOX could induce apoptosis and enhance anti-tumor effect under mild acidic TME.

\section{Conclusion}

In summary, we successfully constructed $N P_{P L G A}$ i.e. PLGA grafted $\gamma-\mathrm{Fe}_{2} \mathrm{O}_{3}$ NPs with high dual POD-like and CAT-like activities under different conditions. Under acidic TME conditions, NPPLGA showed POD-like mimetic activity, and could effectively catalyze the decomposition of $\mathrm{H}_{2} \mathrm{O}_{2}$ to produce high toxicity of $\cdot \mathrm{OH}$ through typical Fenton catalytic reaction, leading to lung adenocarcinoma A549 cell death. At the same time, under the neutral TME condition, NPPLGA 
exhibited CAT-like simulation activity, and could decompose $\mathrm{H}_{2} \mathrm{O}_{2}$ to form $\mathrm{H}_{2} \mathrm{O}$ and $\mathrm{O}_{2}$, thereby reducing the oxidative damage of $\mathrm{H}_{2} \mathrm{O}_{2}$ to lung adenocarcinoma A549 cells. More importantly, $N P_{P L G A}$ of POD-like activity combined with the anti-tumor drug DOX, which can induce the obviously increasing apoptosis rate and enhanced anti-tumor effect for lung adenocarcinoma A549 cells. This present work therefore indicates an essential opportunity towards the development of an effective biomimetic nanoplatform with dual inorganic nanozymes to simulate the catalytic activity of lung tumor treatment.

\section{Acknowledgements}

This study was supported by College of Bioengineering, Henan University of Technology; Henan Bioengineering Research Center; Henan Provincial People's Hospital; School of Pharmacy, Henan University.

\section{Authors' contributions}

Xueqin Wang presented the idea, supervised the wholework, manuscript modification and fnancial support, Miao Cui, Fan Ouyang, and Yuqi Guo performed experiments, data analysis and interpretation, and the manuscript writing. Ruifang Li, Shaofeng Duan and Tiandi Xiong designed experiments, technical assistance and fnal approval of manuscript. Huiru, Zhang and Yunlong Wang contributed equally to this work. All authors read and approved the final manuscript.

\section{Funding}

This work was supported by the China Postdoctoral Science Foundation (No. 2019M652541), Innovation Scientists and Technicians Troop Construction Projects of Henan Province (No. 192101510001), the Scientific and Technological Project of Henan Province (No. 182102210 394), 
the Young Core Instructor Program in Higher Education Institution of Henan province (No. 2018 GGJS 067), the Young Core Instructor Program from Henan University of Technology (No. 214 200 55). Appendix A. Supplementary data: Supplementary data associated with this article can be found in on-line attachments.

\section{Availability of data and materials}

All data and materials are available in the manuscript.

\section{Ethics approval and consent to participate}

Not applicable.

\section{Consent for publication}

The manuscript has been read and approved by all the named authors.

\section{Competing interests}

The authors declare no conflict of interest.

\section{Author details}

${ }^{1}$ College of Bioengineering, Henan University of Technology, Zhengzhou, Henan 450001, P.R. China; ${ }^{2}$ Henan Bioengineering Research Center, Zhengzhou, 450046, P.R.China; ${ }^{3}$ Henan Provincial People's Hospital, Zhengzhou 450003, P.R. China; ${ }^{4}$ School of Pharmacy, Henan University, Kaifeng, Henan 475004, P.R. China.

\section{References}

1. Gao S, Lin H, Zhang H, Yao H, Chen Y, Shi J. Nanocatalytic tumor therapy by biomimetic dual 
inorganic nanozyme-catalyzed cascade reaction. Adv. Sci. 2018;6:1801733.

2. Li SR, Huang YC, Liu JR, Wang EK, Wei H. Nanozymes in analytical chemistry: from in vitro detection to live bioassays. Prog. Biochem. Biophys. 2018;45:129-147.

3. LinY, Ren J, Qu X. Catalytically active nanomaterials: a promising candidate for artificial enzymes. Acc. Chem. Res. 2014;47:1097-105.

4. Kumar S, Bhushan P, Bhattacharya S. Facile synthesis of Au@Ag-hemin decorated reducedgraphene oxide sheets: a novel peroxidase mimetic for ultrasensitive colorimetric detection of hydrogen peroxide and glucose. RSC Adv. 2017;7:37568-77.

5. Fei H, Dong J, Feng Y, Allen CS, Wan C, Volosskiy B, Li M, Zhao Z, Wang Y, Sun H, An P, Chen W, Guo Z, Lee C, Chen D, Shakir I, Liu M, Hu T, Li Y, Kirkland AI, Duan X, Huang Y. General synthesis and definitive structural identification of $\mathrm{MN}_{4} \mathrm{C}_{4}$ single-atom catalysts with tunable electrocatalytic activities. Nat. Catal. 2018;1:63.

6. Zhang Z, Zhang X, Liu B, Liu J. Molecular imprinting on inorganic nanozymes for hundred-fold enzyme specificity. J. Am. Chem. Soc. 2017;139:5412-19.

7. Wu L, Wan G, Hu N, He Z, Shi S, Suo Y, Wang K, Xu X, Tang Y, Wang G. Synthesis of porous $\mathrm{CoFe}_{2} \mathrm{O}_{4}$ and its application as a peroxidase mimetic for colorimetric detection of $\mathrm{H}_{2} \mathrm{O}_{2}$ and organic pollutant degradation. Nanomaterials. 2018;8:451.

8. Tian R, Sun J, Qi Y, Zhang B, Guo S, Zhao M. Inflfluence of $\mathrm{VO}_{2}$ nanoparticle morphology on the colorimetric assay of $\mathrm{H}_{2} \mathrm{O}_{2}$ and glucose. Nanomaterials. 2017;7:347.

9. Vallabani NV, Karakoti AS, Singh S. ATP-mediated intrinsic peroxidase-like activity of $\mathrm{Fe}_{3} \mathrm{O}_{4}$-based nanozyme: One step detection of blood glucose at physiological $\mathrm{pH}$. Colloids Surf. B Biointerfaces. 2017; 153:52-60. 
10. Wu J, Li S, Wei H. Integrated nanozymes: facile preparation and biomedical applications. Chem. Commun. 2018;54:6520-30.

11. Zhou Y, Liu B, Yang R, Liu J. Filling in the gaps between nanozymes and enzymes: challenges and opportunities. Bioconjugate. Chem. 2017;28:2903-09.

12. Mahmoudi M, Simchi A, Imani M, Hafeli OU. Superparamagnetic iron oxide nanoparticles with rigid cross-linked polyethylene glycol fumarate coating for application in imaging and drug delivery. J. Phys. Chem. C. 2009;113:8124-31.

13. Tang C, He Z, Liu H, Xu Y, Huang H, Yang G, Xiao Z, Li S, Liu H, Deng Y, Chen Z, Chen H, He N. Application of magnetic nanoparticles in nucleic acid detection. J. Nanobiotechnol. 2020;18:62.

14. Zhu F, Tan G, Zhong Y, Jiang Y, Cai L, Yu Z, Liu S, Ren F. Smart nanoplatform for sequential drug release and enhanced chemo-thermal effect of dual drug loaded gold nanorod vesicles for cancer therapy. J. Nanobiotechnol. 2019;17:44.

15. Chung HT, Hsiao KJ, Hsu CS, Yao M, Chen CY, Wang WS, Huang MD. Iron oxide nanoparticle-induced epidermal growth factor receptor expression in human stem cells for tumor therapy. Acs Nano. 2011;5:9807.

16. Zhu L, Zhou Z, Mao H, Yang L. Magnetic nanoparticles for precision oncology: theranostic magnetic iron oxide nanoparticles for image-guided and targeted cancer therapy. Nanomedicine (Lond). 2017;12:73-87.

17. Soares PIP, Laia TAC, Carvalho A, Pereira CL, Coutinho TJ, Ferreira MI, Borges PJ. Iron oxide nanoparticles stabilized with a bilayer of oleic acid for magnetic hyperthermia and MRI applications. Appl. Surf. Sci. 2016;383:240-247. 
18. Hemalatha T, Prabu P, Gowthaman KM. Fabrication and characterization of dual acting oleyl chitosan functionalised iron oxide/gold hybrid nanoparticles for MRI and CT imaging. Int. J. Bio. Macromol. 2018;112:250-257.

19. Olsvik O, Popovic T, Skjerve E, Cudjoe SK, Hornes E, Ugelstad J, Uhlen M. Magnetic separation techniques in diagnostic microbiology. Clin. Microbiol. Rev. 1994;7:43.

20. Gupta KA, Curtis GSA. Lactoferrin and ceruloplasmin derivatized superparamagnetic iron oxide nanoparticles for targeting cell surface receptors. Biomaterials. 2004;25:3029-40.

21. Gupta KA, Curtis GSA. Lactoferrin and ceruloplasmin derivatized superparamagnetic iron oxide nanoparticles: preparation, characterization and their influence on human dermal fibroblasts in culture. Proc. 30th Annu. Symp. Controlled Release Bioact. Mater. 2003;30:788.

22. Min C, Shao H, Liong M, Yoon JT, Weissleder R, Lee H. Mechanism of magnetic relaxation switching sensing. ACS Nano. 2012;6:6821-28.

23. Cheon J, Lee HJ. Synergistically integrated nanoparticles as multimodal probes for nanobiotechnology. Acc.Chem. Res. 2008;41:1630-40.

24. Ebrahimisadr S, Aslibeiki B, Asadi R. Magnetic hyperthermia properties of iron oxide nanoparticles: the effect of concentration. Physica C. 2018;549:119-21.

25. Espinosa A, Di RC, Kolosnjaj-Tabi J, Flaud P, Pellegrino T, Wilhelm C. Duality of iron oxide nanoparticles in cancer therapy: amplification of heating efficiency by magnetic hyperthermia and photothermal bimodal treatment. ACS Nano. 2016;10:2436-46.

26. Chen Z, Yin JJ, Zhou YT, Zhang Y, Song L, Song M, Hu S, Gu N. Dual enzyme-like activities of iron oxide nanoparticles and their implication for diminishing cytotoxicity. ACS Nano. 2016;6:4001-12. 
27. Pisanic RT, Blackwell DJ, Shubayev IV, Finones RR, Jin S. Nanotoxicity of iron oxide nanoparticle internalization in growing neurons. Biomaterials. 2007;28:2572-81.

28. Gao L, Zhuang J, Nie L, Zhang J, Zhang Y, Gu N, Wang T, Feng J, Yang D, Perrett S, Yan X. Intrinsic peroxidase-like activity of ferromagnetic nanoparticles. Nat. Nanotech. 2007;2:577-83.

29. Duesterberg CK, Mylon SE, David WT. pH effects on iron-catalyzed oxidation using Fenton's reagent. Environ. Sci. Technol. 2008;42:8522-27.

30. Kang YS, Risbud S, Rabolt JF, Stroeve P. Synthesis and characterization of nanometer-size $\mathrm{Fe}_{3} \mathrm{O}_{4}$ and $\gamma-\mathrm{Fe}_{2} \mathrm{O}_{3}$ particles. Chem. Mater. 1996;8:2209-11.

31. Chen Z, Yin JJ, Zhou TY, Zhang Y, Song L, Song M, Gu N. Dual enzyme-like activities of iron oxide nanoparticles and their implication for diminishing cytotoxicity. ACS Nano. 2012;6:4001-12.

32. Song L, Huang C, Zhang W, Ma M, Chen Z, Gu N, Zhang Y. Graphene oxide-based $\mathrm{Fe}_{2} \mathrm{O}_{3}$ hybrid enzyme mimetic with enhanced peroxidase and catalase-like activities. Colloid. Surf. A 2016;506:747-55.

33. Niu YH, Zhang D, Zhang XS, Zhang LX, Meng FZ, Cai QY. Humic acid coated $\mathrm{Fe}_{3} \mathrm{O}_{4}$ magnetic nanoparticles as highly efficient fenton-like catalyst for complete mineralization of sulfathiazole. J. Hazard. Mater. 2011;190:559-65.

34. Wang N, Zhu HL, Wang LD, Wang QM, Lin FZ, Tang QH. Sono-assisted preparation of highly-efficient peroxidase-like $\mathrm{Fe}_{3} \mathrm{O}_{4}$ magnetic nanoparticles for catalytic removal of organic pollutants with $\mathrm{H}_{2} \mathrm{O}_{2}$. Ultrason. Sonochem. 2010;17:526-33.

35. Shin S, Yoon H, Jang J. Polymer-encapsulated iron oxide nanoparticles as highly efficient fenton catalysts. Catal. Commun. 2008;10:178-82. 
36. Fan J, Yin JJ, Ning B, Wu X, Hu Y, Ferrari M, Anderson JG, Wei J, Zhao Y, Nie G. Direct evidence for catalase and peroxidase activities of ferritin-platinum nanoparticles. Biomaterials. 2011;32:1611-18.

37. Dickinson BC, Chang CJ. Chemistry and biology of reactive oxygen species in signaling or stress responses. Nat. Chem. Biol. 2011;7:504.

38. Wang F, Ju E, Guan Y, Ren J, Qu X. Light-mediated reversible modulation of ROS level in living cells by using an activity-controllable nanozyme. Small. 2017;13:1603051.

39. Zhao J, Cai X, Gao W, Zhang L, Zou D, Zheng Y, Li Z, Chen H. Prussian blue nanozyme with multienzyme activity reduces colitis in mice. ACS Appl. Mater. Interfaces. 2018;10:26108.

40. Gao S, Jin Y, Ge K, Li Z, Liu H, Dai X, Zhang Y, Chen S, Liang X, Zhang J. Self-Supply of O 2 and $\mathrm{H}_{2} \mathrm{O}_{2}$ by a nanocatalytic medicine to enhance combined chemo/chemodynamic therapy. Adv. Sci. 2019;6:1902137.

41. Chen Q, Luo Y, Du W, Liu Z, Zhang S, Yang J, Yao H, Liu T, Ma M, Chen H. Clearable theranostic platform with a $\mathrm{pH}$-independent chemodynamic therapy enhancement strategy for synergetic photothermal tumor therapy. ACS Appl. Mater. Interfaces. 2019;11:18133-44.

42. Qu S, Yang H, Ren D, Kan S, Zou G, Li D. Magnetite nanoparticles prepared by precipitation from partially reduced ferric chloride aqueous solutions. J. Colloid Interface Sci. 1999;215:190-92.

43. Sun YK, Ma M, Zhang Y, Gu N. Synthesis of nanometer-size maghemite particles from magnetite. Colloid. Surf. A 2004;245:15-19.

44. Wang X, Ou Y, Cui L, Xiong T, Guan X, Guo Y, Duan S. Surface coating-modulated peroxidase-like activity of maghemite nanoparticles for a chromogenic analysis of cholesterol. J 
Nanopart Res. 2019;21:1-13.

45. Dong YL, Zhang HG, Rahman ZU, Su L, Chen XJ, Hu J. Graphene oxide-Fe $\mathrm{O}_{4}$ magnetic nanocomposites with peroxidase-like activity for colorimetric detection of glucose. Nanoscale. 2012;4:3969.

46. Singh S. Cerium oxide based nanozymes: redox phenomenon at biointerfaces. Biointerphases. 2016;11:04B202.

47. Giorgio M, Trinei M, Migliaccio E, Pelicci GP. Hydrogen peroxide: a metabolic by-product or a common mediator of ageing signals? Nat. Rev. Mol. Cell Biol. 2007;8:722-28.

48. Han BY, Yuan JP, Wang EK. Sensitive and selective sensor for biothiols in the cell based on the recovered fluorescence of the CdTe quantum dots-Hg (II) system. Anal. Chem. 2009;81:5569-73.

49. Pastore A, Federici G, Bertini E, Piemonte F. Analysis of glutathione: implication in redox and detoxification. Clin. Chim. Acta. 2003;333:19-39.

50. Chamaon K, Stojek J, Kanakis D, Braeuninger S, Kirches E, Krause G, Mawrin C, Dietzmann K. Micromolar concentrations of 2-methoxyestradiol kill glioma cells by an apoptotic mechanism, without destroying their microtubule cytoskeleton. J. Neuro-Oncol. 2005;72:11-16. 


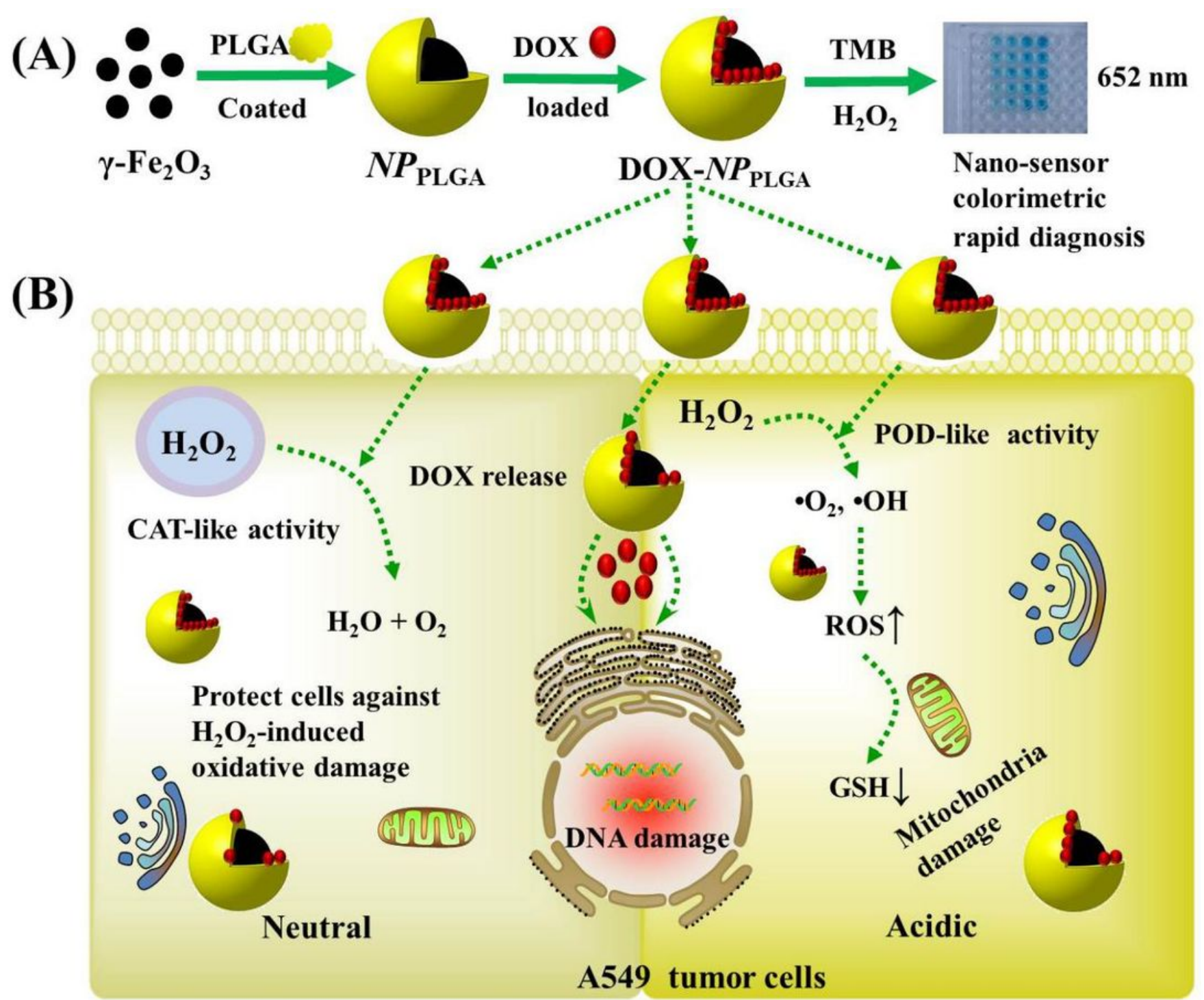

Figure 1

Schematic diagram of the functional pattern of DOX-NPPLGA and its enhanced anti-tumor effect. A Preparation of DOX-loaded NPPLGA and colorimetric determination in lung adenocarcinoma A549 cells. $B$ In a neutral TME, DOX-NPPLGA displayed CAT-like activity by decomposing $\mathrm{H} 2 \mathrm{O} 2$ into $\mathrm{H} 2 \mathrm{O}$ and $\mathrm{O} 2$. In an acidic TME, DOX-NPPLGA released DOX and exhibited POD-like activity to produce highly toxic $\cdot \mathrm{OH}$, which caused the growth of ROS accumulation as well as the decrease of GSH in tumor A549 cells, and the further synergistic effect with DOX, causing efficient cell death. 
(A)

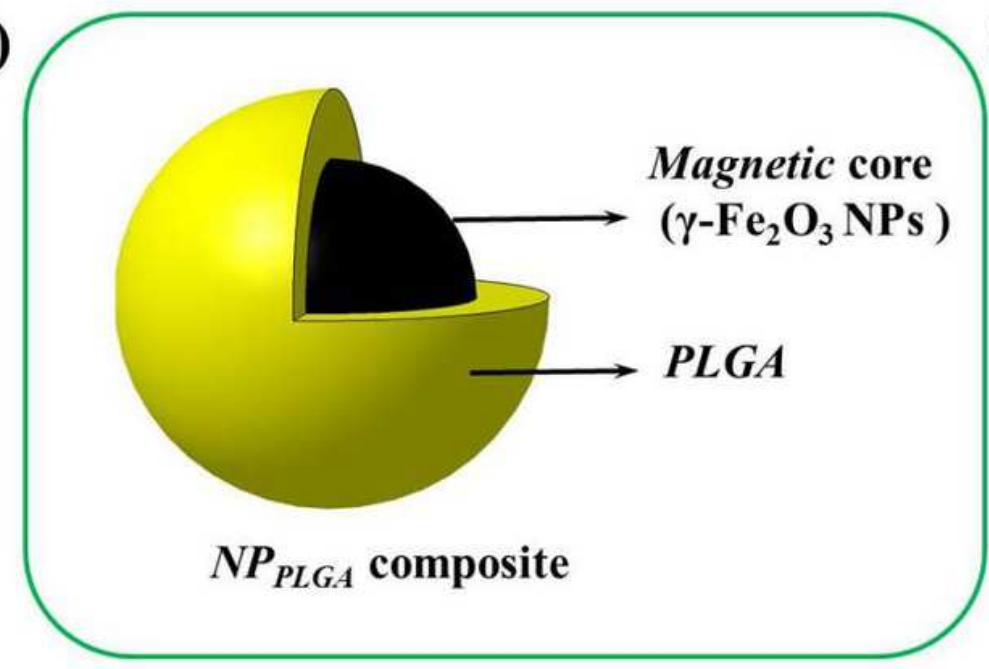

(B)
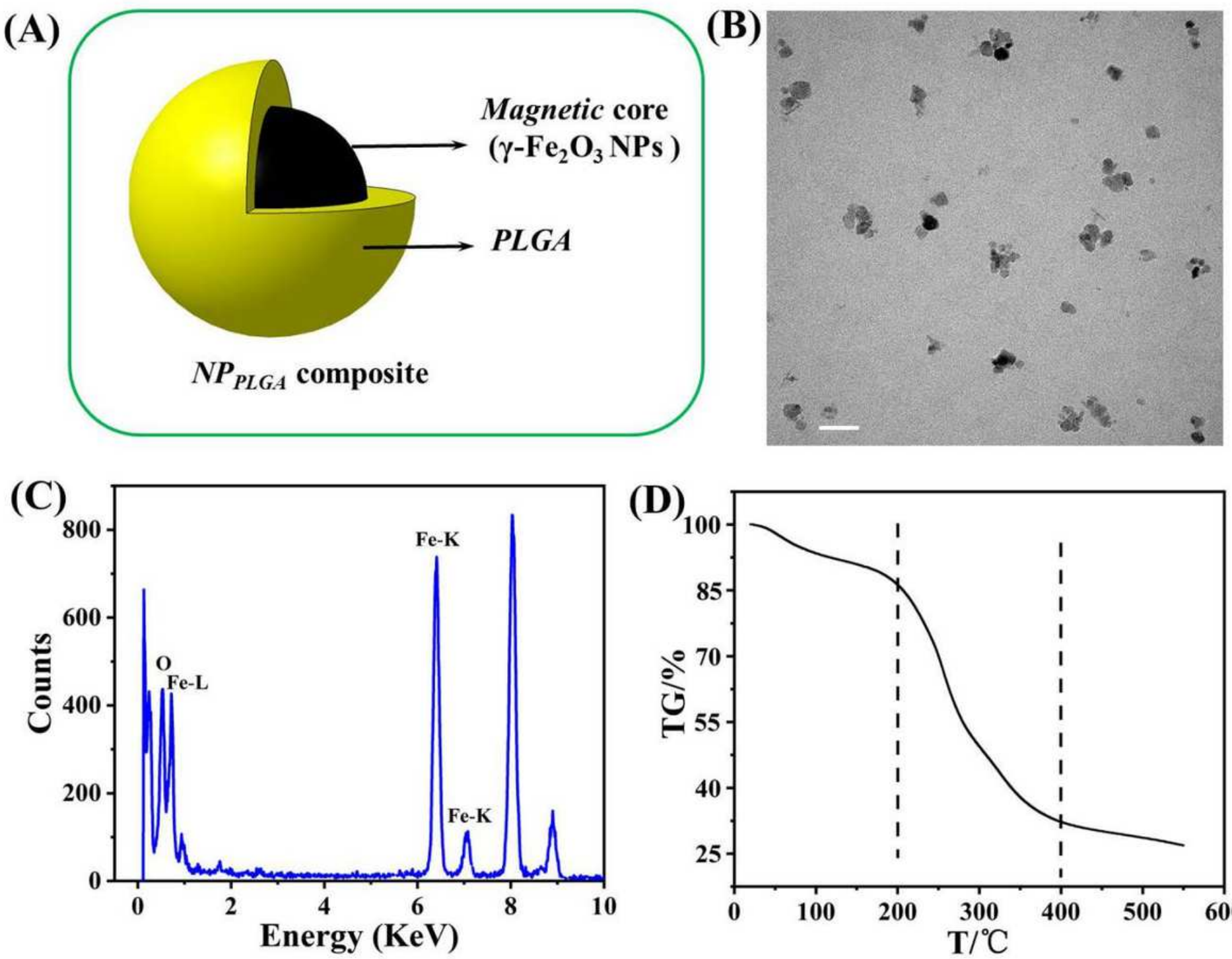

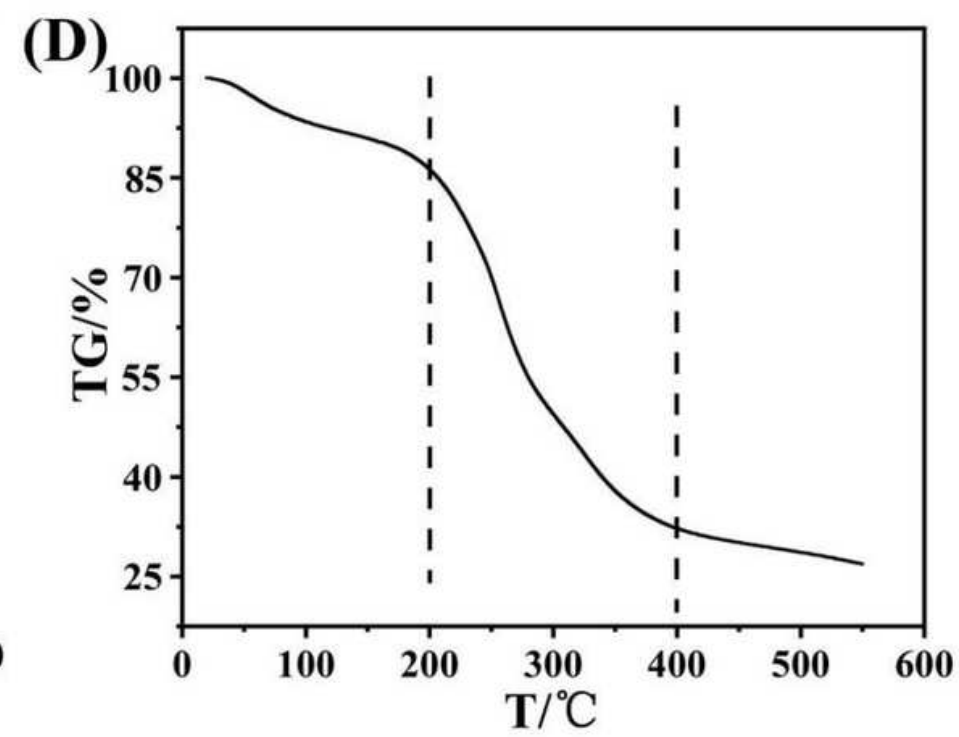

Figure 2

1 A Schematic illustration of the composite NPPLGA. B TEM image of NPPLGA. Scale bar $=50 \mathrm{~nm}$. C EDS spectrum of NPPLGA. D Thermogravimetric curve of NPPLGA. 
(A)

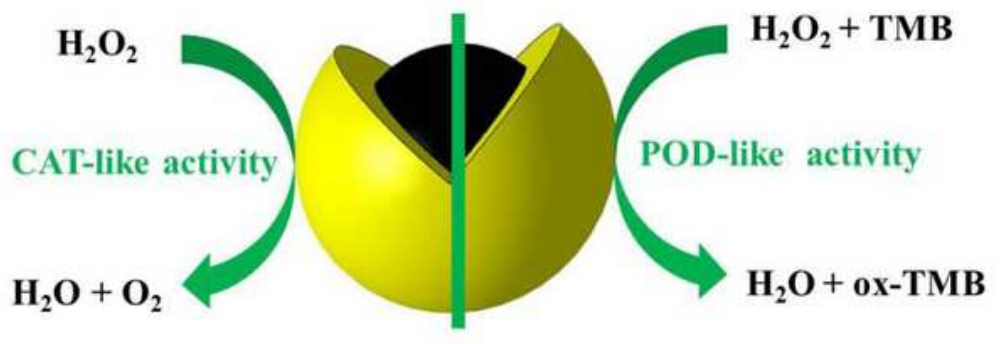

$N P_{P L G A}$ composite

(C)

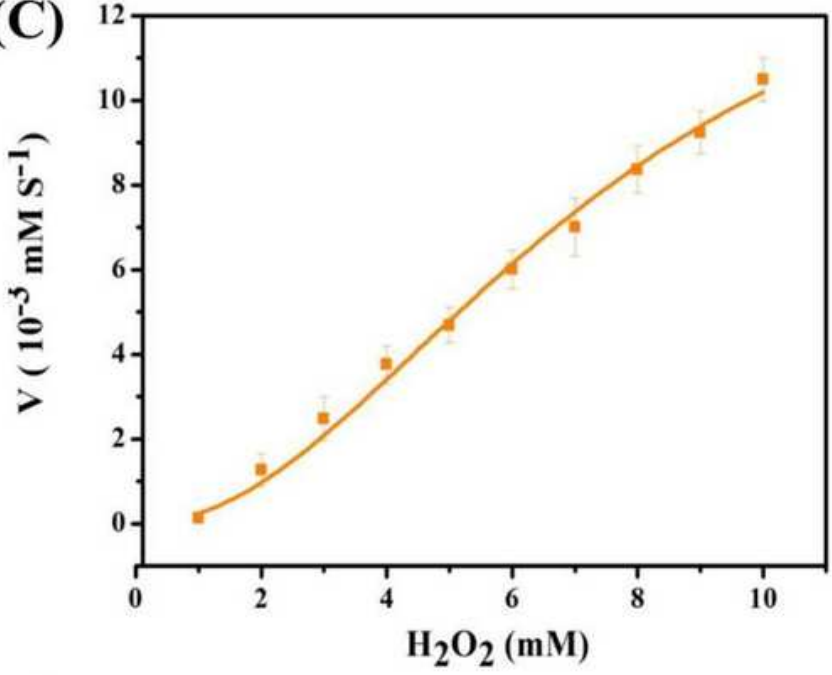

(E)

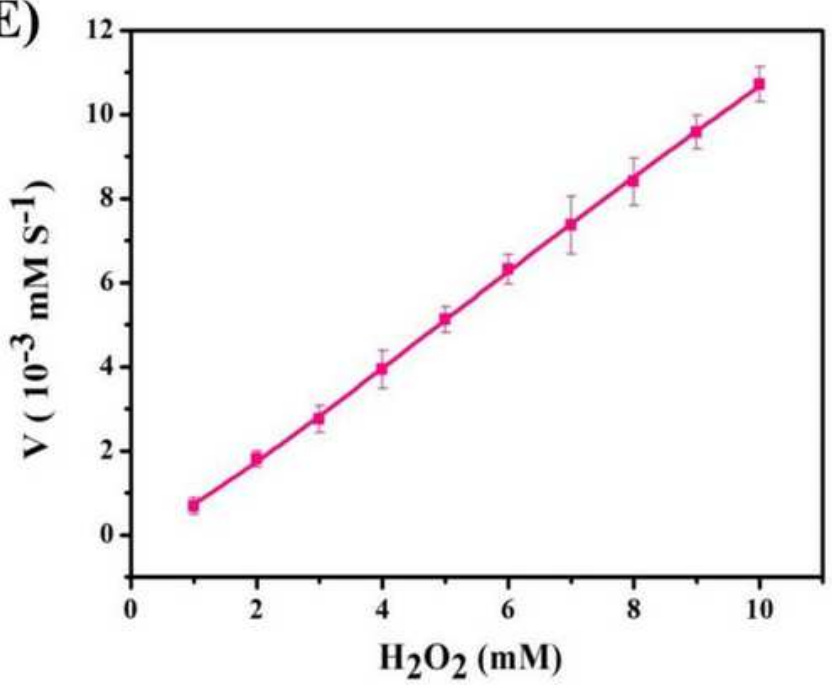

(B)

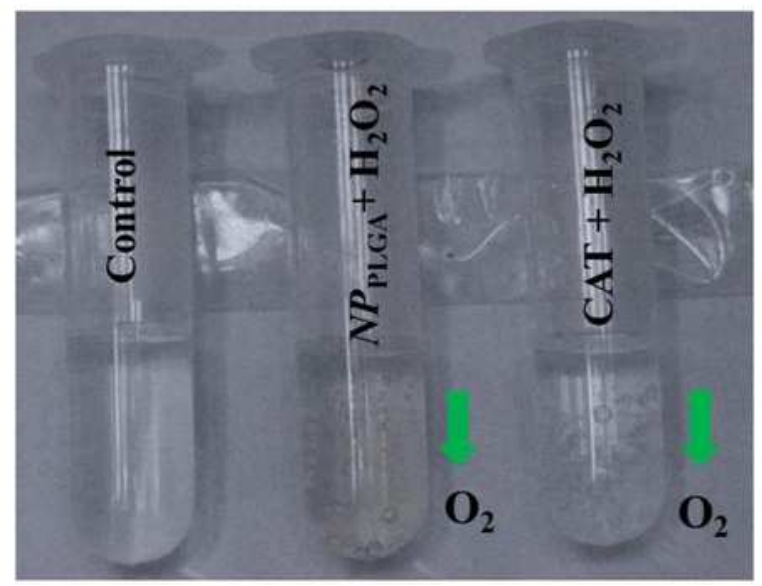

(D)

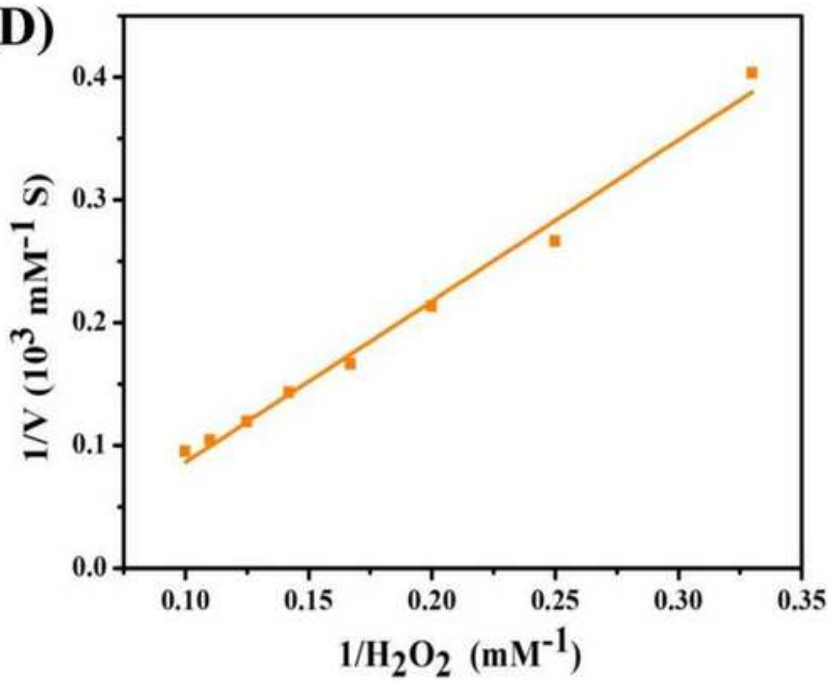

(F)

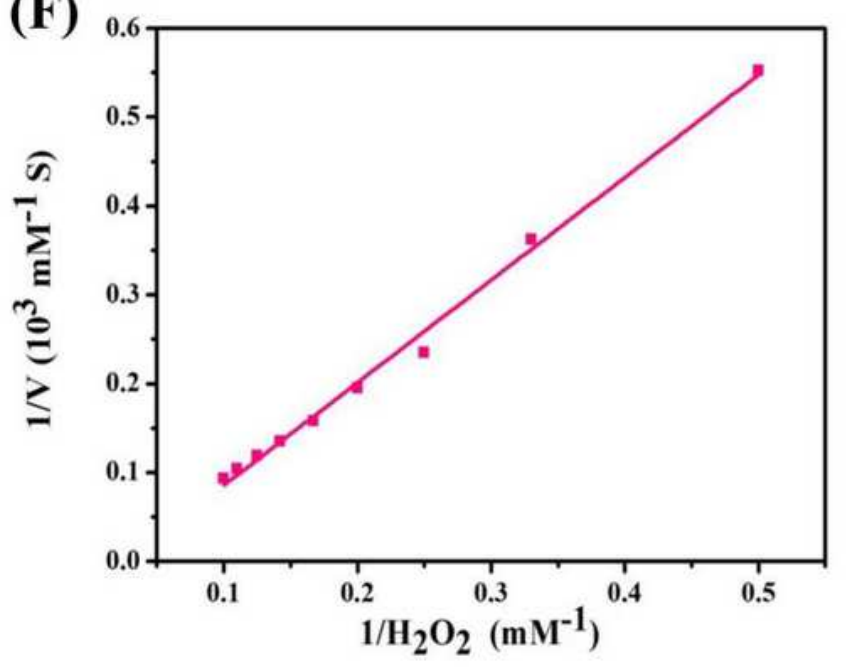

Figure 3

A Schematic illustration for dual enzyme-like catalytic performance of the NPPLGA. B CAT-like activity assay of NPPLGA, both NPPLGA and natural CAT can catalyze $\mathrm{H} 2 \mathrm{O} 2$ to produce $\mathrm{O} 2$ when $\mathrm{H} 2 \mathrm{O} 2$ is available in the system. C Steady-state Kinetic assays for NPPLGA in the presence of $\mathrm{H} 2 \mathrm{O} 2$, and D corresponding double-reciprocal plot. E) Kinetic assays of natural CAT in the presence of $\mathrm{H} 2 \mathrm{O} 2$, and F) corresponding double-reciprocal plot. 

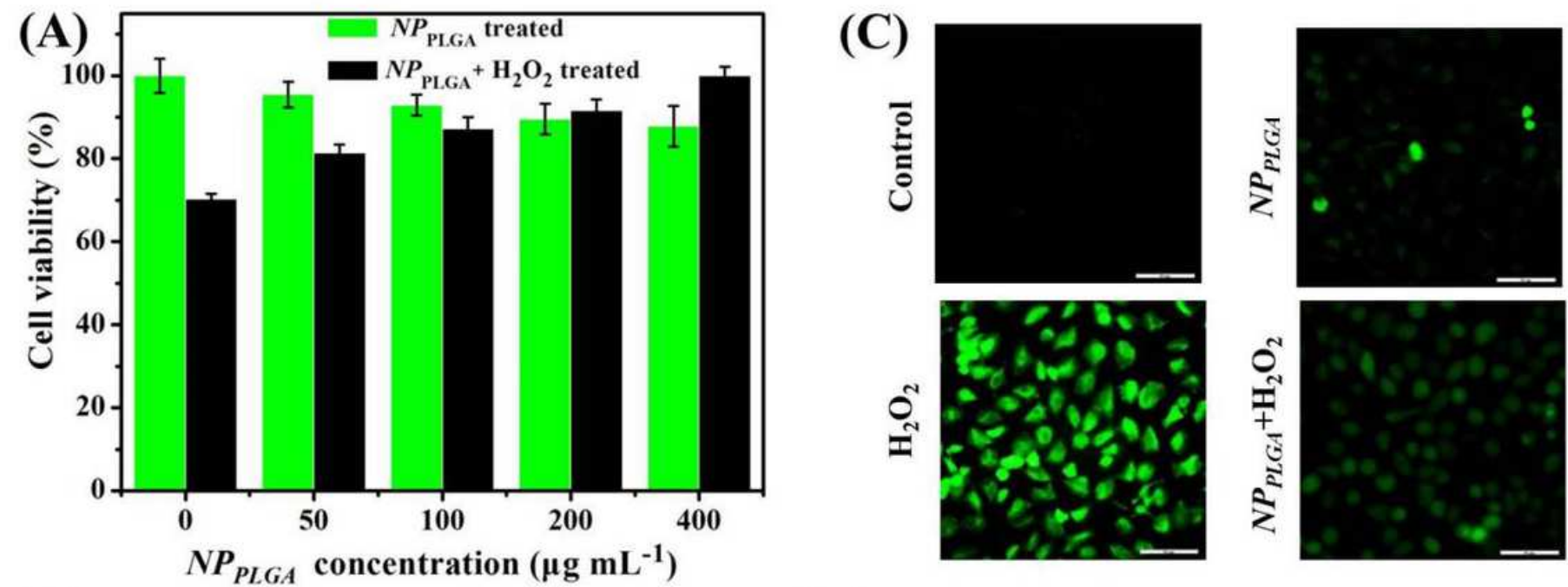

(B)

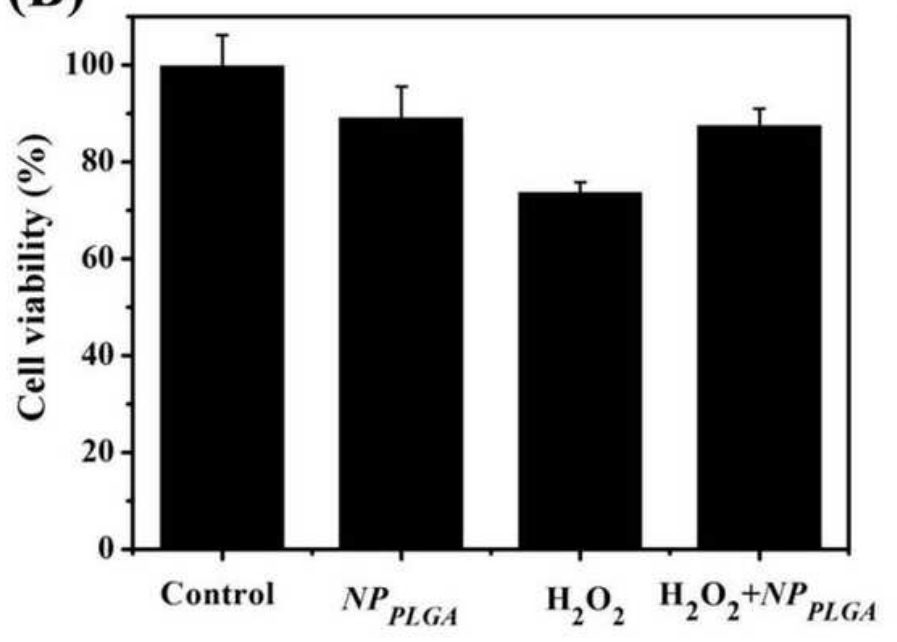

(D)

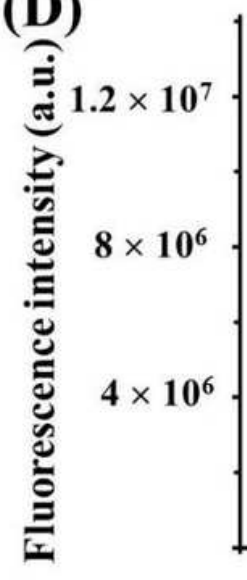

(E)
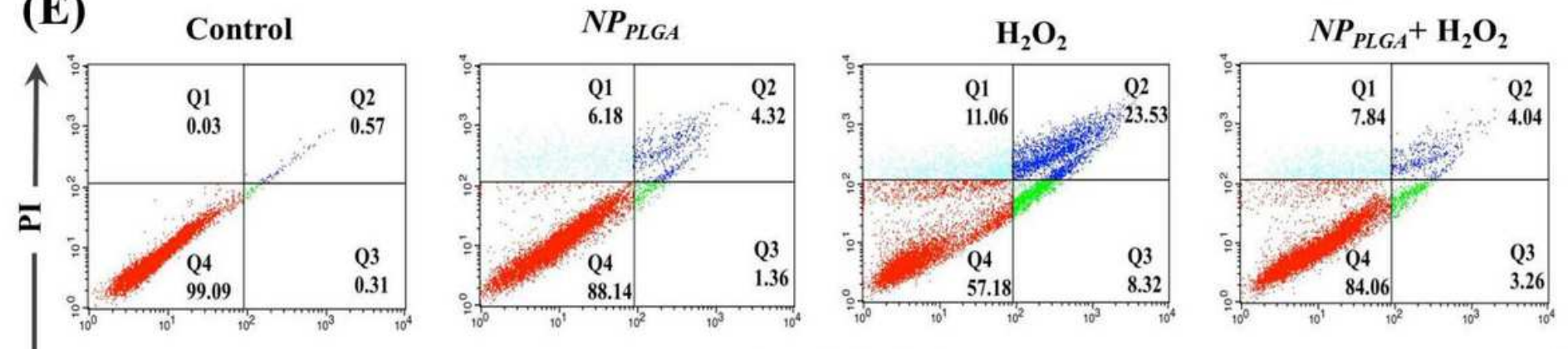

Annexin V-FITC

Figure 4

A Cytotoxicity of NPPLGA and H202-induced oxidative damage assays of treated A549 cells with various concentration of NPPLGA including 50, 100, 200, $400 \mu \mathrm{g} \cdot \mathrm{mL}-1$, and the cells were treated with various concentration NPPLGA and 5 mM H2O2 under neutral TME conditions ( $\mathrm{pH}$ 7.4). B H2O2-induced oxidative damage of A549 cells with different formulation treatments, the cells were treated for $12 \mathrm{~h}$, and the concentration of NPPLGA was $200 \mu \mathrm{g} \cdot \mathrm{mL}-1$. C Assays of ROS production in treated A549 cells for 12 $h$ with different formulations, and $D$ corresponding statistical of the fluorescence intensity analysis in the 
processed cells. E Apoptosis assays of the processed A549 cells with different treatment through flow cytometry utilizing the staining methods of fluorescein Annexin V-FITC-PI double labeling, untreated A549 cells employed as a control. Early apoptosis (bottom right), late apoptosis (upper right), necrotic cells (upper left), and normal cells (bottom left).

(A)

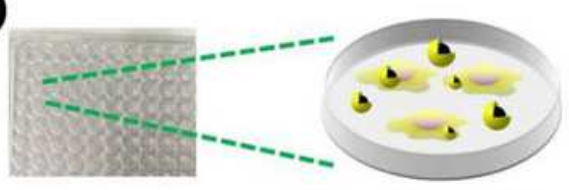

A549 cells and $N P_{P L G A}$ pre-coated
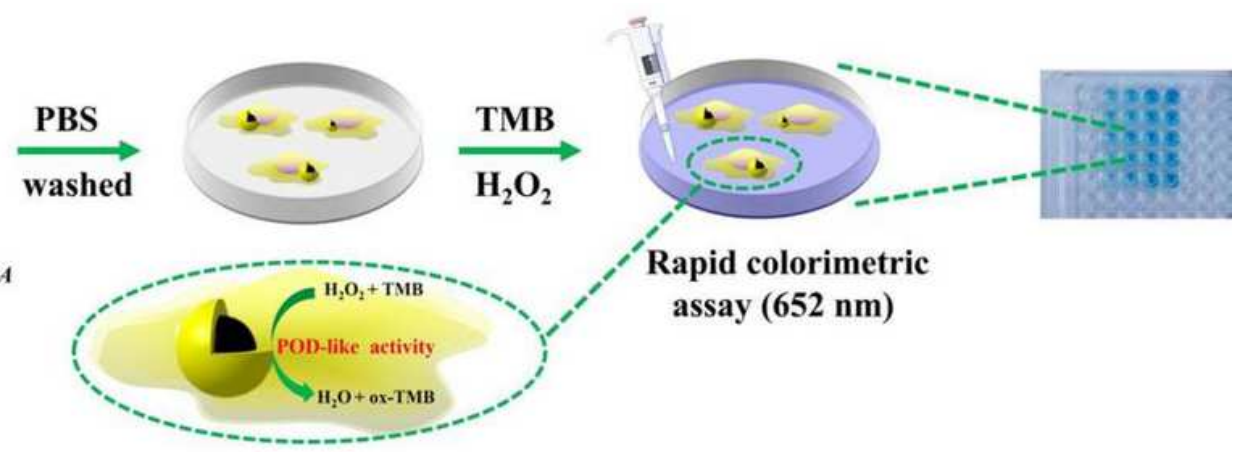

Rapid colorimetric assay $(652 \mathrm{~nm})$
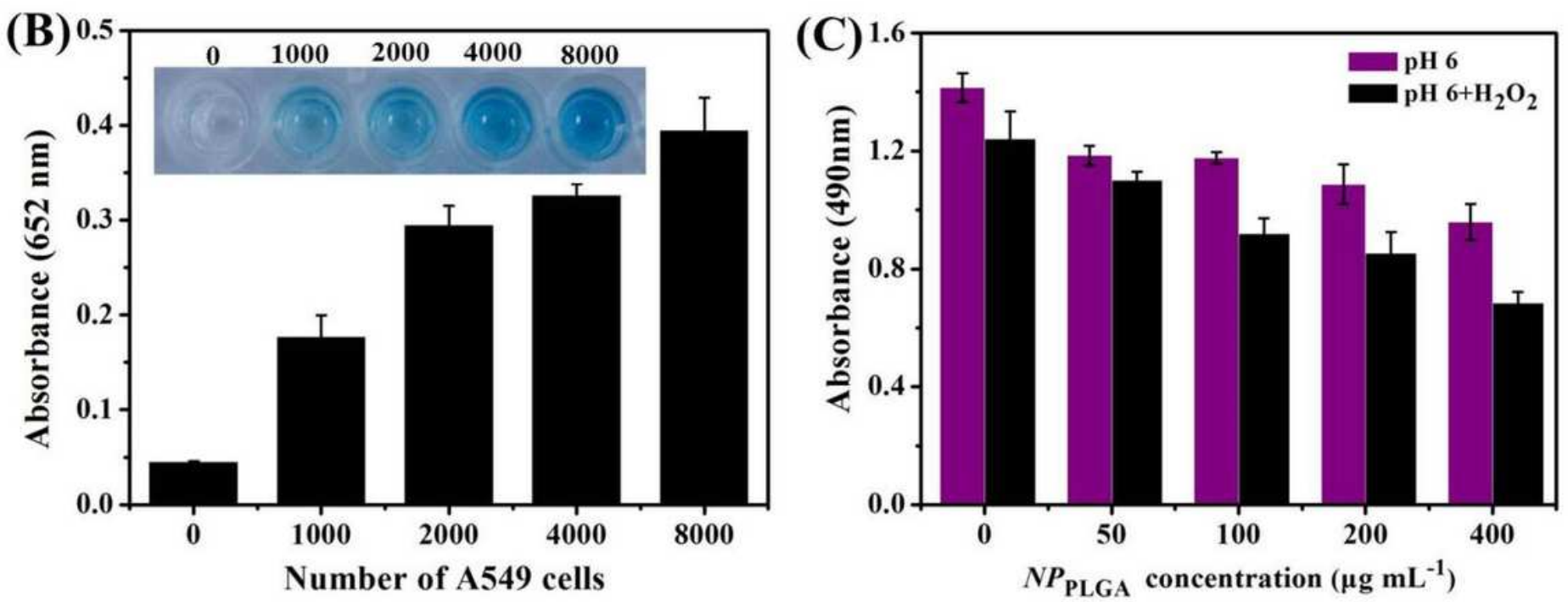

Figure 5

A Schematic illustrated the process of quantitative colorimetric assay of A549 cells via the POD-like performance of NPPLGA, and B A549 cells were detected based on the POD-like activity of NPPLGA in the presence of TMB. Inset: indicates the change of the color related to the various number of A549 cells. C The concentration-dependent cytotoxicity assay of NPPLGA in acidic TME. 
(A) Control
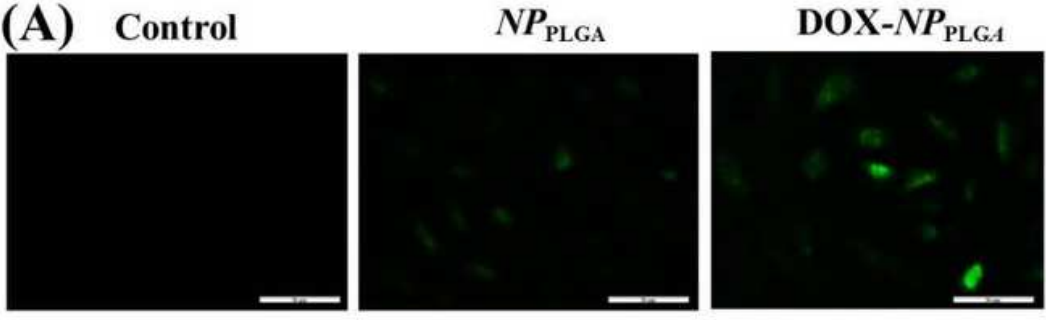

$\mathrm{H}_{2} \mathrm{O}_{2}$

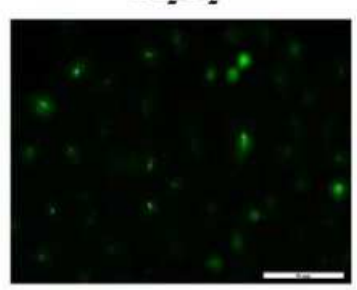

$$
N P_{\text {PLGA }}+\mathrm{H}_{2} \mathrm{O}_{2}
$$

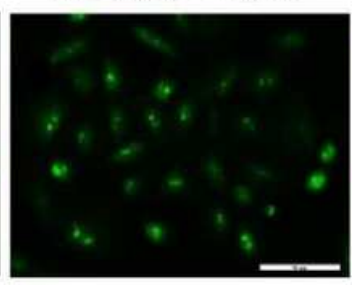

DOX-NP $P_{\mathrm{PLGA}}+\mathrm{H}_{2} \mathrm{O}_{2}$

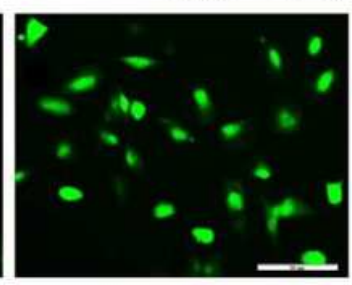

(B)

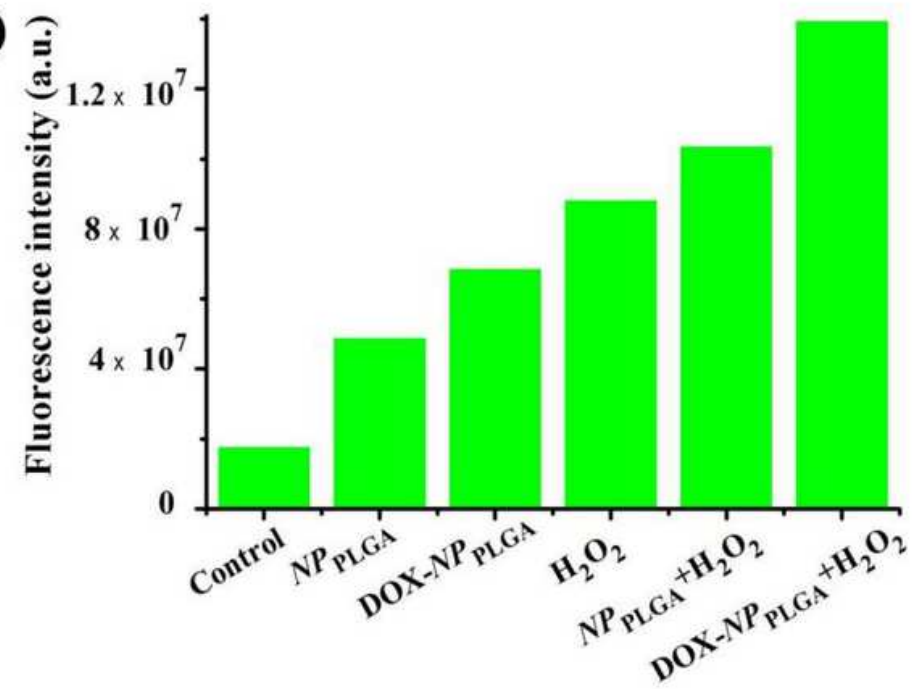

(D)

(C)
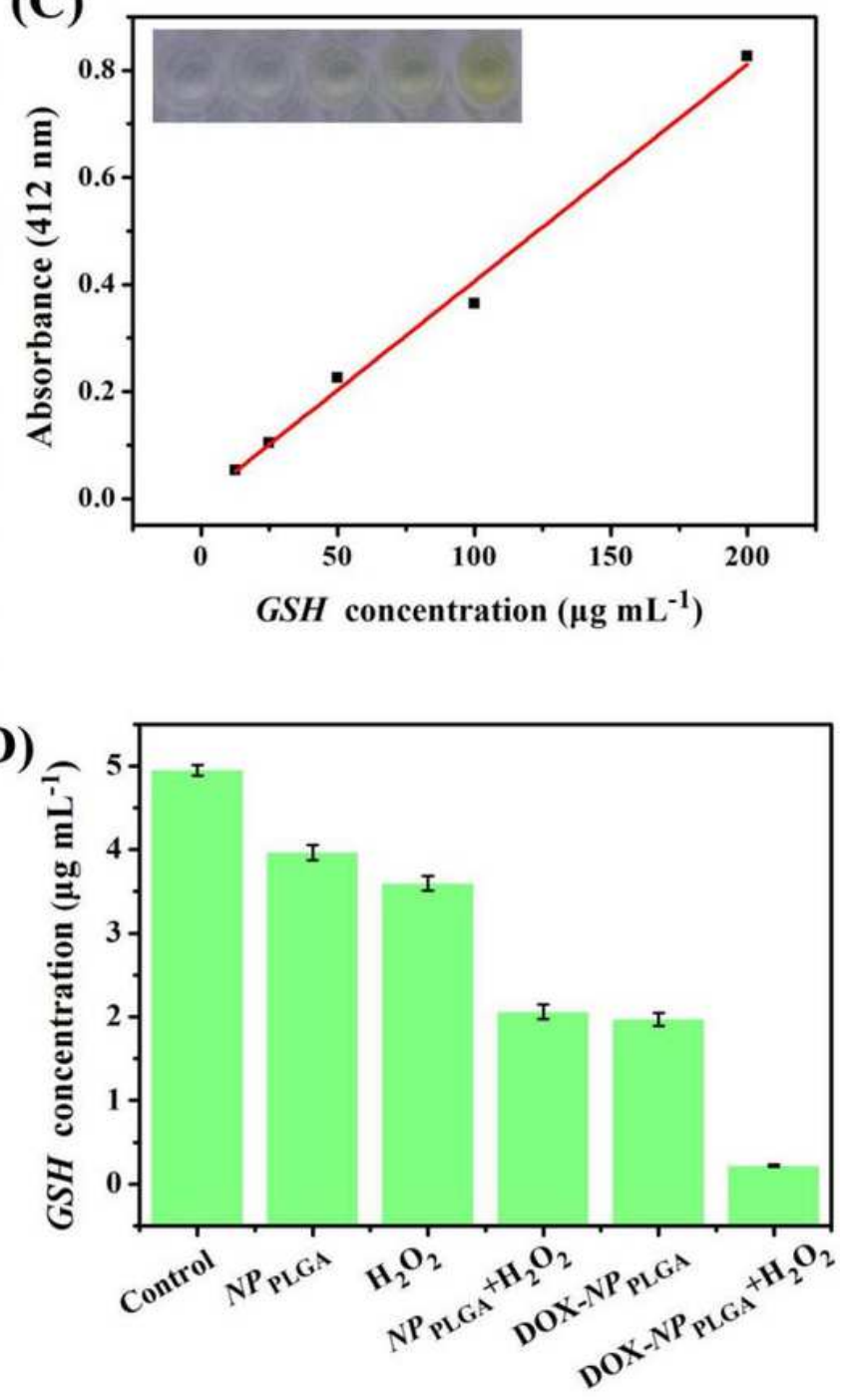

Figure 6

A Assay of intracellular ROS level, fluorescence images of A549 cells after co-incubation with different formulations for $12 \mathrm{~h}$, and stained using ROS fluorescence probe DCFH-DA, and B corresponding fluorescence intensity analysis. Scale bars $=100 \mu \mathrm{m}$. C A dose-dependent linear curve of various concentrations of GSH solutions with the optimum models, and as well as the inserted photos is the photograph of different concentration. D Assay of reduced GSH in the treated A549 cells with different formulations. 


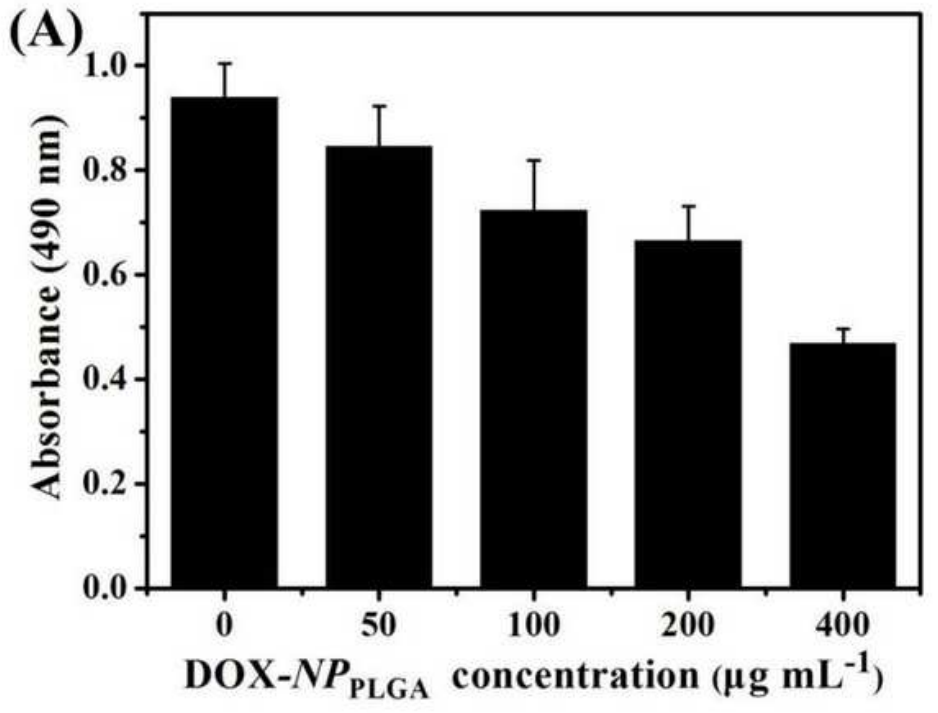

(C) Control
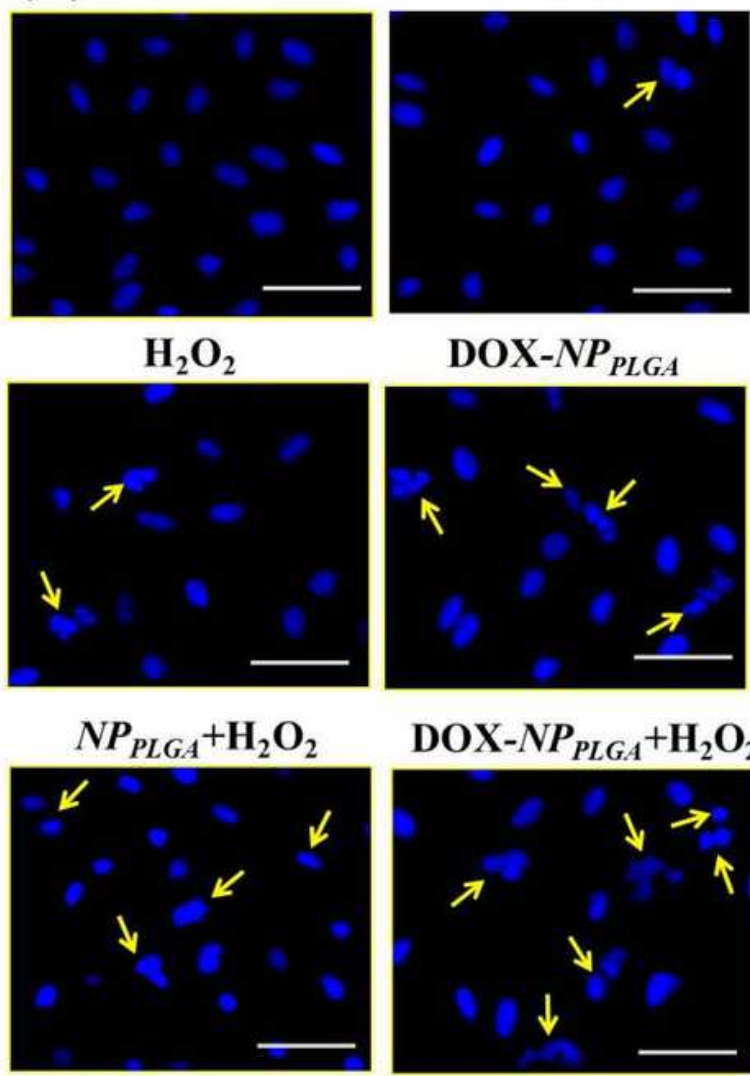
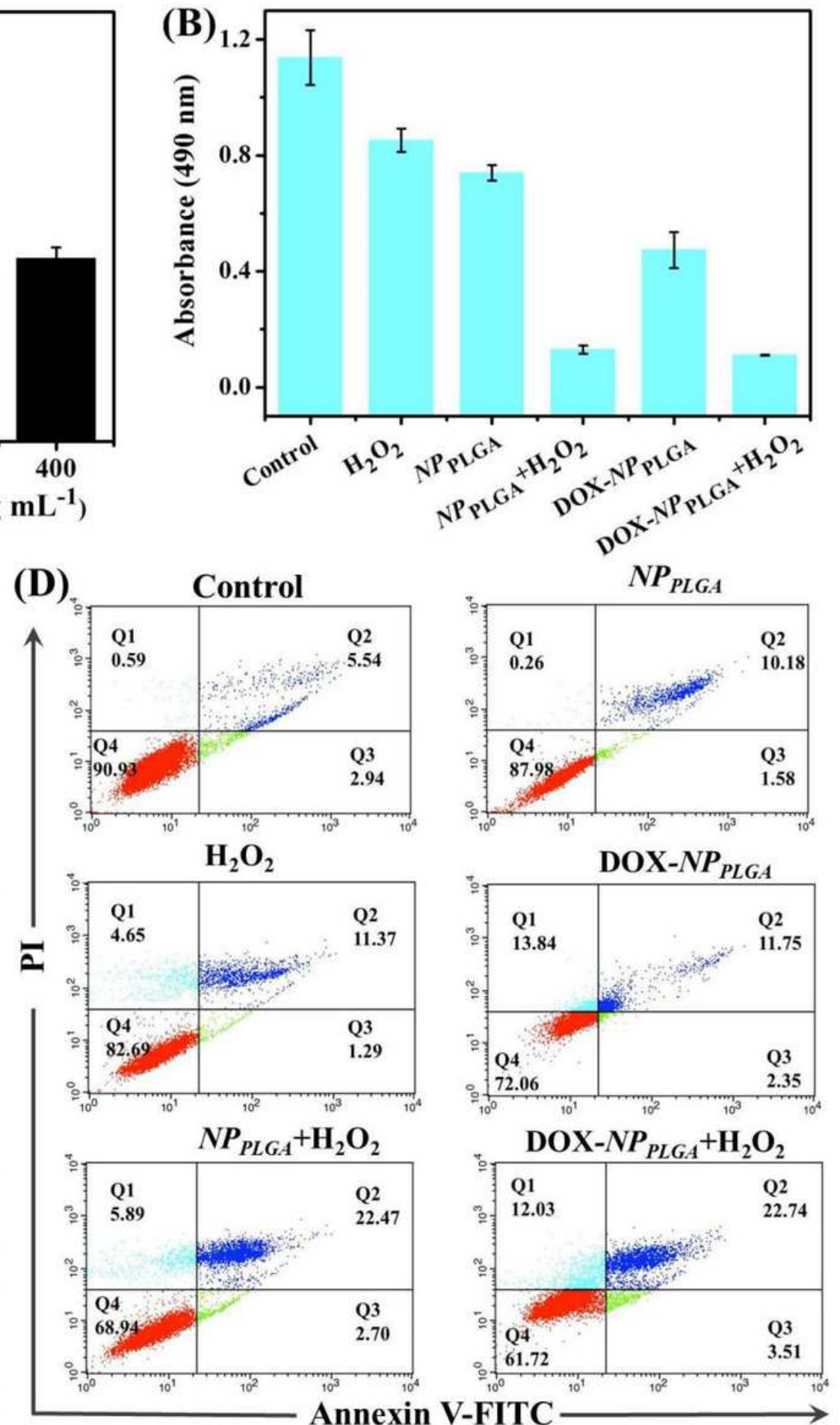

\section{Figure 7}

A Effect of various concentration of DOX-NPPLGA on survival rate of the treated A549 cells. B Effect of different formulations on the cell viability of the treated A549. C The A549 cells with different formulation treatment under acidic TME ( $\mathrm{pH}$ 6.0) were stained via Hoechst H33258. Scale bars $=100 \mu \mathrm{m}$. D Apoptosis assay of the A549 cells with different treatments through flow cytometry by double labeling staining of fluoresce Annexin V-FITC-PI, under acidic TME ( $\mathrm{pH}$ 6.0). Untreated A549 cells employed as control. 